九州大学学術情報リポジトリ

Kyushu University Institutional Repository

\title{
The Chrysomelidae of Japan and the Ryukyu Islands. X : Subfamily Alticinae III
}

Kimoto, Shinsaku

Hikosan biological Laboratory, Department of Agriculture, Kyushu University

https://doi.org/10.5109/22737

出版情報: 九州大学大学院農学研究院紀要. 13 (4)，pp.601-633，1966-02. Kyushu University バージョン：

権利関係 : 
Journal of the Faculty of Agriculture, Kyushu University, Vol. 13, No. 4. February 15, 1966

\title{
The Chrysomelidae of Japan and the Ryukyu Islands. $\mathrm{X}^{1,2)}$ Subfamily Alticinae III
}

\author{
Shinsaku KІмото ${ }^{3)}$
}

\section{Genus Luperomorpha Weise}

Luperomorpha Ws., 1877, Archiv. Naturg. 53 (1) : 202 (type : L. trivialis Ws.).-Heikertinger, 1924, Kol. Rundsch. 11 (1-2): 32 ; 1925, t. c. (3-4) : 51.-Maulik, 1926, Fauna India, Chrysom. \& Halt., 285, 361.-Chen, 1933, Sinensia 3 (9): 227 ; 1934 , op. cit. 5 (3-4) : 233, 345.-Chûjô, 1935, Nat, Hist. Soc. Formosa, Trans. 25: 357.Chen, 1936, Sinensia 7 (6) : 637.-Chûjô, 1937, Nat. Hist. Soc. Formosa, Trans. 27: 113.-Kung \& Chen, 1954, Acta Ent. Sinica 4 (1) : 83. - Gressitt \& Kimoto, 1963, Pac. Ins. Mon. 1B: 747, 860.

Luperocnemus Fairmaire, 1888, Soc. Ent. Belg., Ann. 32 : 43 (type: L. xanthoderus Fairmaire).

\section{Key to Japanese species of Luperomorpha}

1. Surface of pronotum smooth, shining ................................................... 2

Surface of pronotum minutely shagreened.................................................... 3

2. Pronotum slightly convex, closely and distinctly punctate; black, antennae reddish brown with a few apical joints slightly infuscate; legs yellowish brown with femora darker; length $2.3-3.0 \mathrm{~mm}$ tenebrosa

Pronotum distinctly convex, sparsely punctate; black, pronotum yellowish or reddish brown, antennae and legs entirely black or piceous; length $3.2-3.8 \mathrm{~mm}$ collaris

3. Fourth antennal joint slightly shorter than, or subequal to, second and third joints combined

In male specimens fourth antennal joint distinctly longer than second and third joints combined; in female, fourth antennal joint slightly shorter than second

1) Partly supported by a grant from Japan Society, New York City, through B. P. Bishop Museum, Honolulu, Hawaii, U. S. A.

2) Contribution Ser. 2, no. 223, Entomological Laboratory, Kyushu University.

3) Hikosan Biological Laboratory, Faculty of Agriculture, Kyushu University. 
and third joints combined

4. In male specimens lateral margin of elytra with a pair of lateral tuberculations bearing a tuft of hairs, situated on $1 / 6$ to $1 / 5$ from base; yellowish to reddish brown; elytral suture and seven to eight apical joints blackish; length $2.5-2.8 \mathrm{~mm}$ irisae

In male specimens lateral margin of elytra without such a tuberculation; yellowish to reddish brown; scutellum piceous, elytra black, antennae and legs entirely reddish brown; 1ength $2.5-2.8 \mathrm{~mm}$ hidakai

5. Elytra rather closely and distinctly punctate ........................................... 6

Elytra rather sparsely and finely punctate; black, head and thorax reddish brown; leg brown or piceous with posterior femora black or much darker color than in the other segments; length $2.8-3.0 \mathrm{~mm}$ birmanica

6. Frontal tubercles separated from behind by a distinct furrow; reddish brown, elytra black, antennae dark reddish brown with four or five basal joints paler, legs reddish brown, in some cases posterior femora partly blackish; length $2.5-3.2 \mathrm{~mm}$ pryeri

Frontal tubercles not distinctly separated from behind; coloration variable: 1 . black, two or three basal joints paler. 2. black, pronotum reddish brown, antennae blackish with four or five basal joints reddish brown, legs reddish brown with posterior femora black; length $2.5-3.2 \mathrm{~mm}$ funesta

\section{Luperomorpha tenebrosa (Jacoby)}

Phyllotreta tenebrosa Jacoby, 1885, Zool. Soc. Lond., Proc. 1885: 731 (Japan: Kobe, Kumamoto, Yuyama; BM).-Chûjô, 1936, Nat. Hist. Soc. Formosa, Trans. 27: 116, 119 (Honshu, Kyushu).

Luperomorpha tenebrosa: Chûjô \& Kimoto, 1961, Pac. Ins. 3 (1) : 184 (Japan).

Distribution: Japan (Hokkaido, Honshu, Sado I., Shikoku, Kyushu).

Fukuoka: Mt. Hiko; Kashii and Hirao in Fukuoka City ; Mt. Wakasugi ; Mt. Scfuri; Tashiro in Yame-gun; Mt. Fukuchi; Ino in Kasuya-gun. Okayama: Kamocho in Tomata-gun. Osaka: Mt. Myoken. Nagano: Shirahone; Karuizawa; Omachi City; Asama-Onsen. Yamanashi: Masutomi; Amari-yama; Komagatake. Kanagawa: Yugawara. Tokyo: Mt. Takao. Hokkaido: Engaru in Abashiri; Nibushi in Akan Prov.; Ashoro, Nukabira in Tokachi.

Hosts: Astragalus sinicus; Beta vulgaris var. altissima; Broussonetia Kazinoki; B. papyrifera; Chrysanthemum cornonrium; Citrus deliciosa (after Chûjô \& Kimoto, 1961).

\section{Luperomorpha collaris (Baly)}

Aphthona? collaris Baly, 1874, Ent. Soc. Lond., Trans. 1874: 198 (Japan: Nagasaki; $\mathrm{BM})$.

The records of $L$. collaris besides the type series are considered as $L$. pryeri Baly.

Distribution: Japan (Hokkaido, Kyushu).

Kagoshima: Shiroyama in Kagoshima City (1 ex., 6. Apr. 1959, S. Fukuda leg.). Hokkaido: Nibushi in Akan Prov. (1 ex., 4. June. 1957, M. Takahashi leg.). 


\title{
Luperomorpha irisae n. sp.
}

\author{
Aphthona preyeri: Jacoby, 1885, Zool. Soc. Lond., Proc. 1885: 730 (Nikko, Kuriga- \\ lıara).-Chûjo, 1937, Nal. Hisl. Suc. Furmusa, Trans. 27 : 119, 120 (Hunshu, Kyu- \\ shu). \\ Luperomorpha preyeri: Chûjô \& Kimoto, 1961, Pac. Ins. 3 (1): 184 (Japan).
}

Oblong oval; reddish brown, suture of elytra and postero-lateral margin of scutellum piceous; three basal joints of antennae reddish brown, three following joints dark reddish brown and rest of them piceous; legs reddish brown.

Vertex obsoletely shagreened, sparsely impressed with minute punctures; frontal tubercles transverse, delimited from behind by a distinct furrow, and their anterointerior corners extending towards interior margin of eyes, inter-antennal space distinctly raised. Antennae rather robust, first joint relatively long, club-shaped, second small, subspherical, slightly longer than wide, third subequal in length to second, and strongly narrowed towards base, fourth nearly $11 / 2$ times as long as third, widened towards apex, fifth very slightly shorter than fourth, fifth to tenth subequal in length to each other, eleventh distinctly longer than tenth and its apex pointed. Pronotum transverse, nearly $11 / 3$ times as wide as long, anterior margin nearly straight, basal margin nearly straight at middle and rounded at sides, lateral margin rounded, widest at middle, and narrowed towards anterior margin and more strongly narrowed towards posterior margin; anterior corner feebly thickened, obtuse; posterior corner widely rounded; disc distinctly shagreened throughout, distinctly and rather closely punctate, a shallow transverse furrow impressed at middle of disc. Scutellum triangular, with narrowly rounded, surface shagreened. Elytra subparallel-sided, surface distinctly and closely punctate.

In male specimens, lateral margin of elytra with a pair of lateral tuberculations bearing a tuft of hairs, situated on $1 / 6$ to $1 / 5$ from base.

Length $2.5-2.8 \mathrm{~mm}$.

Distribution: Japan (Honshu, Shikoku, Kyushu).

Holotype: Karuizawa in Nagano Pref. (7-14. July. 1959, K. Morimoto leg.) (Entomological Laboratory, Kyushu University).

Paratopotypes: 5 exs., same as the holotype.

Paratypes: Mt. Daisen in Tottori Pref. (1 ex., 10. July. 1954, M. Chûjô leg.). Mt. Myoken in Osaka Pref. (1 ex., 5. June. 1952, 1 ex., 9. July. 1953, K. Sawada leg.). Obina-yama, Kofu City in Yamanashi Pref. (1 ex., 28. July. 1956, I. Kamiya leg.). Shosenkyo in Yamanashi Prcf. (1 cx., 22. July. 1956, H. Kamiya leg.). Yunomata, Shimokita Pen., in Aomori Pref. (1 ex., 9. Aug. 1957, T. Saigusa leg.).

Host : Iris sanguinea (after Chûjô \& Kimoto, 1961).

\section{Luperomorpha hidakai $\mathrm{n} . \mathrm{sp}$.}

Oblong-oval. Reddish brown; elytra black; underside piceous to black.

Vertex obsoletely shagreened and sparsely impressed with minute punctures; frontal tubercles transverse, contiguous, distinctly delimited from behind by a deep furrow; inter-antennal space distinctly raised. Antennae rather slender, first joint long, club-shaped, second the shortest, third subequal to second in length but dis- 
tinctly more slender; fourth nearly as long as half length of third, and slightly shorter than second and third combined; fifth slightly shorter than fourth but slightly robuster than fourth; remainders subequal in length and shape to each other; eleventh slightly longer than tenth and its apex pointed. Pronotum transverse, nearly $11 / 3$ times as wide as long; anterior margin feebly produced anteriorly, lateral margin rounded, widest almost at middle and distinctly narrowed anteriorly and more strongly so posteriorly; basal margin nearly straight at middle, and rounded at sides; anterior corner feebly thickened, obtuse; posterior corner widely rounded; disc distinctly shagreened throughout, sparsely and finely punctate. Scutellum triangular with apex rounded, surface shagreened. Elytra rounded laterally, widest almost at middle, surface distinctly and rather closely punctate and its interstices finely granulated.

Length $2.5-2.8 \mathrm{~mm}$.

Distribution: Ryukyu Is. (Okinawa Is.).

Holotype: Yona in Okinawa Is. (16-18. Aug. 1958, T. Hidaka leg.) (Entomological Laboratory, Kyushu University).

Paratopotypes: 8 exs., same as the holotype.

\section{Luperomorpha birmanica (Jacoby)}

Aphthona birmanica Jac., 1892, Mus. Civ. Genova, Ann. 32 : 920 (Burma).

Luperomorpha birmanica: Maulik, 1926, Fauna India, Chrysom. \& Halt., 363.-Chen, 1934, Sinensia 5 (3-4): 348, fig. 71 (Hainan).-Gressitt \& Kimoto, 1963, Pac. Ins. Mon. 1B: 861 (Burma, S. China, N. Vietnam).

Luperomorpha nobilis: Chûjô, 1935, Nat. Hist. Soc. Formosa, Trans. 25: 207 (Ishigaki in Loochoos); 1937, op. cit. $27: 113,114$ (Loochoo, Formosa, China).-Nakane \& Kimoto, 1961, Kontyû 29 (2): 109 (Ishigaki).

Luperomorpha discoides birmanica: Kung \& Chen, 1954, Acta Ent. Sinica 4: 97.

This is the first record of the species from Japan. Until tody this species has been recorded as nobilis Weise, originally described from W. China. The record of nobilis from Taiwan may be referable here.

This species is rather variable in coloration of the dorsal surafce. The specimens taken from the Loo-choos show a coloration described in the key, but ones occurring in SE Asia show the following variations.

1) Head black; pronotum reddish brown; elytra yellowish brown with marginal area black, in some cases black area expands and brownish area becomes smaller and spot-like; ventral surface reddish brown with metathorax blackish; legs reddish brown with posterior femora blackish. 2) Head reddish brown; elytra black with a broad transverse pale band in middle; pronotum reddish brown. 3) Entirely yellowish brown.

Distribution: Burma, S. China, N. Vietnam, Ryukyu Is. (Ishigaki).

Sakishima group: Ishigaki Is. (1 ex., 25. Jan. 1953, T. Shiraki leg.; 1 ex., 20-23. Dcc. 1952, G. E. Bohart leg.); Ohama in Ishigaki Is. (1 ex., 6. Feb. 1953, 2 exs., 7. Feb. 1953, T. Shiraki leg.; 2 exs., 20-23. Aug. 1958, T. Hidaka leg.); Shiraho in Ishigaki Is. (1 ex., 26. Feb. 1953, T. Shiraki leg.). 


\section{Luperomorpha pryeri (Baly)}

Aphthona? pryeri Baly, 1874, Ent. Soc. Lond., Trans. 1874: 198 (Japan: Yokohama, Nagasaki; BM).

Luperomorpha? collaris : Chûjô, 1936, Nat. Hist. Soc. Formosa, Trans. 27 : 113 (Kyushu ; Formosa, China).-Chûjô \& Kimoto, 1961, Pac. Ins. 3 (1): 184 (as a synonym of funesta Baly).

Phyllotreta funesta var. collaris Chûjô, 1940, Kontyû 14 (3) : 117 (Japan: Nishitoyonaga-mura in Kochi Pref.; CHU.so).

The species which have been identified as $L$. pryeri are erroneous and should be referred to $L$. irisae Kimoto which is described in this paper. As Gressitt \& Kimoto, 1963, stated, the specimens recorded as collaris Baly from China are to be identified as $L$. xanthodera (Fairmaire). The records of collaris from Taiwan seem to be erroneous and need further investigation.

Distribution: Japan (Shikoku, Kyushu, Tsushima, Yakushima).

Fukuoka: Mt. Hiko; Mt. Fukuchi. Kumamoto: Mt. Ichifusa. Kagoshima: Satamisaki; Shiroyama in Kagoshima City. Yakushima: Kosugidani. Kochi: Makiyamamura in Kami-gun.

\section{Luperomorpha funesta (Baly)}

Phyllotreta funesta Baly, 1874, Ent. Soc. Lond., Trans. 1874: 196 (Japan: Tsu Sima; BM).-Chûjô, 1937, Nat. Hist. Soc. Formosa, Trans. 27 : 116, 118 (Hokkaido, Honshu, Kyushu, Tsushima).

Luperomorpha funesta: Chûjô \& Kimoto, 1961, Pac. Ins. 3 (1) : 184 (Japan).

Distribution: Japan (Hokkaido, Honshu, Shikoku, Kyushu).

Fukuoka: Mt. Wakasugi; Mt. Hiko; Nakatashiro, Kuroki-machi in Yame-gun. Kochi: Kuroson. Kyoto: Seriu. Nagano: Kiso-Fukushima; Shirahone; Asama-Onsen. Kanagawa: Yugawara. Aomori: Yunomata in Shimokita Pen. Hokkaido: Kuccharo and Nibushi in Akan Prov.

\section{Genus Phyllotreta Stephens}

Phyllotreta Steph., 1839, Man. Brit. Col., 291 (type: Chrysomela nemorum L.; Europe). -Chapuis, 1875, Gen. Col. 11: 73.-Heikertinger, 1924, Kol. Rundsch. 11(1-2): 33, 59, figs. 5-6.-Maulik, 1926, Fauna India, Chrys. \& Halt. 377.-Chen, 1933, Sinensia 3: 228; 1934, op. cit. 5: 234, 371.-Chûjo, 1935, Nat. Hist. Soc. Formosa, Trans. 25 : 357.-Chen, 1936, Sinensia 7 (6) : 638.-Chûjô, 1937, Nat. Hist. Soc. Formosa, Trans. 27 : 115. Heikertinger, 1941, Kol. Rundsch. 27 : 25; 1942, Ent. Blätt. 38: 138; 1950, Kol. Rundsch. 31 (4-6) : 140.--Gressitt \& Kimoto, 1963, Pac. Ins. Mon. $1 \mathrm{~B}: 747,873$.

\section{Key to Japanese species of Phyllotreta}

1. Dorsal surface not entirely black 2 Black; antennae black with three basal joints reddish brown; legs reddịsh 
brown with femora blackish; length $2.0-2.2 \mathrm{~mm} . \ldots \ldots \ldots \ldots \ldots \ldots \ldots \ldots \ldots \ldots \ldots$ atra

2. Anterior and middle legs almost entirely reddish brown ........................ 3

Anterior and posterior femora blackish........................................... 5

3. Boundary of a yellowish marking of elytra clearly defined ........................4

Boundary of a yellowish marking of elytra not clearly defined; elytra largely yellowish brown with lateral, apical and sutural areas narrowly blackish; antennae black with three basal joints reddish brown; legs entirely reddish brown; head, pronotum, scutellum and underside black; length $2.0 \mathrm{~mm}$

brevistriata

4. 우: Fifth antennal joint distinctly longer than fourth; antennae almost entirely reddish brown; legs reddish brown with posterior femora blackish; head, pronotum, scutellum and underside black; length $2.0 \mathrm{~mm}$ ochripes:

우: Fifth antennal joints not longer than fourth; antennae black with three basal joints reddish yellow; legs reddish yellow with dorsal surface of posterior femora blackish; head, pronotum, scutellum and underside black; male unknown; length $2.0 \mathrm{~mm}$ chujoe

5. Large in size; a yellowish stripe on elytra narrow and almost straight; black; three basal joints of antennae brownish; legs dark reddish brown with femora blackish; length $2.2-2.5 \mathrm{~mm}$

rectilineata

Small in size; a yellowish stripe on elytra much broader than in the preceding species and distinctly curved laterally; black, three basal joints paler; legs dark reddish brown with femora blackish; length $2.0-2.5 \mathrm{~mm}$... striolata

\section{Phyllotreta atra (Fabricius) (Fig. 2c)}

Altica atra Fabricius, 1775, Syst. Ent., 115 (Europe).

Phyllotreta atra: Weise, 1888, Ins. Deutschl. 6: 865, 876.-Heikertinger, 1912, in Reitter, Fauna Germ. 4: 177, pl. 149, fig. 4; 1941, Kol. Rundsch. 27 (4-6) : 72 (Europe, Caucasus, C. Asia, Turkestan).

This is the first record of the species from Japan.

Distribution: Europe, Caucasus, C. Asia, Turkestan, Japan (Hokkaido).

Hokkaido: Engaru in Abashiri (4 exs., 6. Aug. 1955, 1 ex., 11. Aug. 1955, K. Morimoto leg.) ; Ashoro in Tokachi (14 exs., 23. May. 1957, 7 exs., 31. May. 1957, T. Takahashi leg; 1 ex., 26. July. 1959, K. Morimoto leg.); Nukabira in Tokachi (1 ex., 21-23. July. 1959, K. Morimoto leg.).

Hosts: In Europe, many kinds of Curuciferous plants.

\section{Phyllotreta brevistriata n. sp. (Figs. 1, 2b)}

Head, pronotum scutellum, and underside black; antennae black with three basal joints reddish brown, elytra largely yellowish brown with lateral, apical and sutural areas, including humeri, narrowly blackish; boundary of a marking on elytra not clearly defined; legs entirely reddish brown.

Vertex distinctly and rather closely punctate, and its surface minutely wrinkled;

* This description was prepared by the Japanese specimen. Unfortunately, I hạve not examined any male specimens collected in Japan. 
frontal tubercles indistinct. $\Lambda$ ntennae rather robust, about half length of body, first longest, club-shaped; second almost half length of first and subequal to third in length, third more slender than second; fourth $11 / 3$ times as long as third but robuster than third; fifth subequal to third in length but robuster; sixth distinctly shorter than fifth; seventh to eleventh subequal to each other in length and shape, and also subequal to fifth. Pronotum onc and half times as wide as long, anterior margin almost straight, lateral margin feebly rounded, anterior corner truncate, posterior corner larger than $90^{\circ}$, posterior margin almost straight at middle and running forwardly to posterior corner; surface transversely convex, distinctly and rather closely punctate, interstices finely shagreened. Scutellum semicircular, shagreened. Elytra distinctly widened from base to before middle and narrowed towards apex; surface strongly and closely punctate.

Length $2.0 \mathrm{~mm}$.

This species much resembles $P$. armoraciae Koch, which is widely distribut-

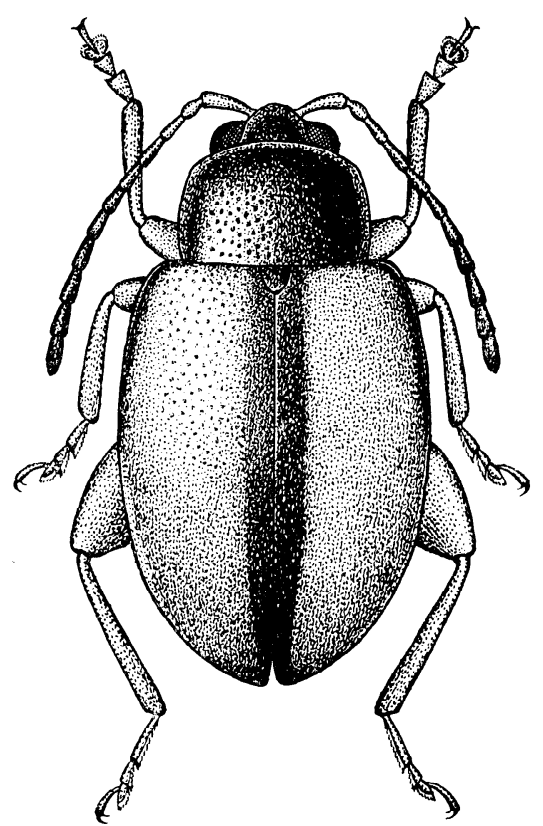

Fig. 1. Phyllotreta brevistriata n. sp. ing in Europe, Siberia and N. America, but may be separable from it in having the brownish black humeri of elytra, entirely yellowish brown legs and differently truncatc apcx of aedcagus.

Distribution: Japan (Hokkaido).

Holotype: Higashikawa in Kamikawa, Hokkaido (22. July. 1955, S. Kimoto leg.) (Entomological Laboratory, Kyushu University).

Paratype: Ashoro in Tokachi (1 ex., 23. May. 1957, M. Takahashi leg.).

\section{Phyllotreta ochripes (Curtis)}

Altica ochripes Curtis, 1837, Brit. Ent. 2: 630, figs (Europe).

Phyllotreta ochripes: Yuasa, 1934, Kontyû 8 (2): 109 (Japan: Hirosaki, Ibaragi).Chûjo, 1937, Nat. Hist. Soc. Formosa, Trans. 27: 116, 117 (Honshu; Siberia, Europe). -Heikertinger, 1941, Kol. Rundsch. 27 (1-3): 52 (Europe, Caucasus, Siberia, Japan). -Chûjô \& Kimoto, 1961, Pac. Ins. 3 (1): 118 (Japan, Siberia, Caucasus, Europe). -Gressitt \& Kimoto, 1963, Pac. Ins. Mon. 1B : 873, 874 (Europe, Caucasus, Siberia, Japan).

Distribution: Europe, Caucasus, Japan (Honshu, Kyushu).

Fukuoka: Mt. Kora in Kurume City (1 ex., 29. May. 1954, I. Hiura leg.).

Hosts: In Europe, Alliaria officinalis ; Cardamine amara; Sisymbrium alliaris ; Rorippa amphibia, 


\section{Phyllotreta chujoe Madar}

Phyllotreta chujoe Madar, 1959, Niponius, Takamatsu 1 (2): 3, fig. 2 (Japan: Kurokawa in Niigata Pref. ; CHuso).-Chûjô \& Kimoto, 1961, Pac. Ins. 3 (1): 188 (Japan). Distribution: Japan (Honshu).

\section{Phyllotreta rectilineata Chen (Fig. 2a)}

Phyllotreta rectilineata Chen, 1939, Sinensia 10 (1-6): 50 (China).-Heikertinger, 1950, Kol. Rundsch. 31 (4-6): 140 (Tonkin, China).-Gressitt \& Kimoto, 1963, Pac. Ins. Mon. 1B : 873, 874 (Japan, S. China, N. Vietnam).

Phyllotreta chinensis Heikertinger, 1941, Kol. Rundsch. 27: 28 (Kiangsi, Tonkin); 1950, op. cit. 31 (4-6) : 140 (synonymized).

Phyllotreta chinensis f. shirahatai Madar, 1959, Niponius, Takamatsu 1 (2): 5, figs. 3 (Japan: Odajima-mura in Yamagata Pref.; CHujo). New Synonymy

Distribution: N. Vietnam, S. China, Japan (Kyushu).

Fukuoka: Tashima in Fukuoka City (5 exs., 7. June. 1953, T. Yoshida leg.); Mt. Hiko (1 ex., 2. July. 1954, T. Yoshida leg.).

\section{Phyllotreta striolata (Fabricius)}

Crioceris striolata Fabricius, 1803, Index Syst. Eleuth., 38 (Europe).

Phyllotreta sinuata: Baly, 1874, Ent. Soc. Lond., Trans. 1874: 196 (China, Japan, E. Siberia, Europe).

Phyllotreta vittata: Miwa, 1931, Syst. Cat. Formosan Col., 191 (Japan, Formosa).Chûjô, 1937, Nat. Hist. Soc. Formosa, Trans. 27: 116, 117 (Honshu; Siberia, Europe).-Heikertinger, 1941, Kol. Rundsch. 27 (1-3) : 50 (Europe, Caucasus, Siberia, C. \& E. Asia).

Phyllotreta striolata: Yuasa, 1950, in Iconogra. Ins. Japonicorum, 1207, fig. 3473 (Japan).-Chûjô \& Kimoto, 1961, Pac. Ins. 3 (1) : 189 (Holarctic region ; Japan, Ryukyu Is.).-Gressitt \& Kimoto, 1963, Pac. Ins. Mon. 1B : 873, 971 (Holarctica; Japan, China, Korea, Ryukyu, Taiwan, Vietnam).

Distribution: Holarctica ; Japan (Hokkaido, Honshu, Hachijo-jima, Shikoku, Okinoshima, Kyushu, Tsushima), Ryukyu Is. (Tokara, Amami-Oshima, Okinawa, Borodino Is., Miyako, Ishigaki, Iriomote), China, Korea, Taiwan, N. Vietnam, Thailand, Sumatra.

Sakishima group: Komi in Iriomote Is.; Ishigaki Is.; Miyako Is. Okinawa group : Nakijin, Tamagusuku in Okinawa Is. Tokara group: Takarajima.

Fukuoka: Mt. Wakasugi; Mt. Hiko; Mt. Inunaki; Otani in Kokura City. Kagoshima: Sata-misaki. Kochi: Jinzenji in Kochi City ; Makiyama-mura in Kami-gun. Okayama: Kamo-cho in Tomata-gun. Yamanashi: Atago-yama in Kofu City. Tochigi: Nikko. Aomori: Yunomata in Shimokita Pen. Hokkaido: Ashoro in Tokachi ; Higashikawa in Kamikawa ; Engaru in Abashiri ; Aizankei, Yukomanbetsu and Asahidake at Mt. Daisetsu.

Hosts: Various kinds of cultivated plants belonging to the family Cruciferae, 


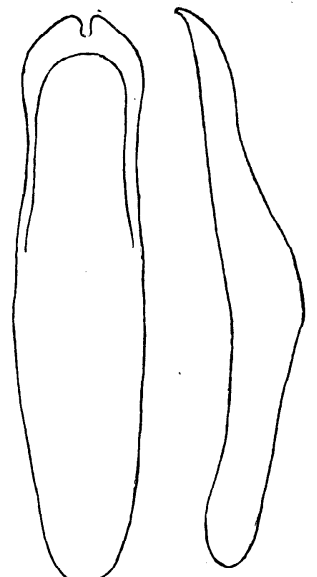

a

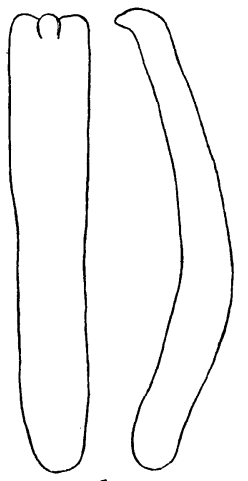

$\mathrm{b}$

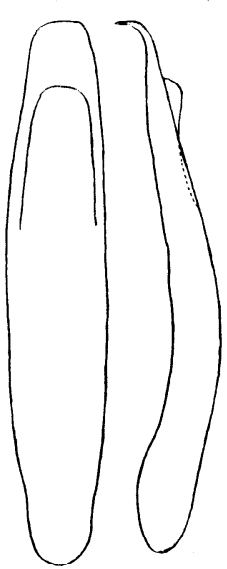

c

Fig. 2. Male genitalia: a, Phyllotreta rectilineata Chen; b, P. brevistriata n. sp.; c, $\boldsymbol{P}$. atra (Fabricius).

\section{Genus Aphthona Chevrolat}

Aphthona Chevr., 1842, in d'Orbigny, Dict. Univ. d'Hist. Nat. 2 : 5 (Altica cyparissiae; first species mentioned).-Chapuis, 1875, Gen. Col. 11: 72.-Heikertinger, 1924, Kol. Rundsch. 11: 30.-Maulik, 1926, Fauna India, Chrys. \& Halt., 366.-Chen, 1933, Sinensia $3: 226 ; 1934$, op. cit. $5: 233,349$.-Chûjô, 1935, Nat. Hist. Soc. Formosa, Trans. 25 : 357.-Chen, 1936, Sinensia 7 (6) : 638.-Chûjô, 1937, Nat. Hist. Soc. Formosa, Trans. 27: 95.-Chen, 1939, Sinensia 10 (1-6): 74.-Heikertinger, 1944, Kol. Rundsch. 30 (1-3): 123; 1948, op. cit. 31 : 128.-Gressitt \& Kimoto, 1963, Pac. Ins. Mon. 1B : 747, 865.

\section{Key to Japanese species of Aphthona}

1. Body above not yellowish brown but bluish or greenish 2

Body yellowish; head, four or five apical joints of antennae, scutellum, sutural margin of elytra narrowly and posterior femora blackish; meso- and metathorax and abdomen piceous to black; length $2.0 \mathrm{~mm}$ foudrasi

2. Elytral surface not granulated. 3

Elytral surface extremely finely and closely granulated and punctate; body above dark green with slight cupreous shimmer; antennae piceous with four or five basal joints yellowish; body beneath black, legs yellowish brown with posterior femora piceous; length $1.8-2.3 \mathrm{~mm}$ strigosa

3. Punctures of pronotum distinct and roundish, always surface of pronotum smooth.

Punctures of pronotum fine and oblong, in most cases surface of pronotum longitudinally wrinkled; body above metallic blue, sometimes cupreous; anțennae black, with four basal joints yellowish brown; body beneath black, 
legs yellowish brown, with posterior femora and basal half of two anterior pairs of femora blackish; length $2.0-2.3 \mathrm{~mm}$ formosana

4. Antennae rather slender, preapical antennal joints distinctly longer than twice as long as wide; frontal tubercles rather transverse; inter-antennal space rather distinctly costate; body above bluish black, blue or green; antennae pale piceous, with four or five basal joints yellowish brown or almost entirely fulvous; body beneath black, legs yellowish brown or pitchy brown, with posterior femora blackish; length $1.82 .3 \mathrm{~mm}$.... perminuta

Antennae rather robust, preapical antennal joints almost, or slightly shorter than, twice as long as wide ; frontal tubercles rather vertical; inter-antennal space very feebly raised but not costate; piceous, antennae entirely reddish brown with apical joints slightly infuscate and in some cases basal joints dark reddish brown; legs reddish brown with posterior femora blackish; length $2.0-3.0 \mathrm{~mm}$.... nigrita

\section{Aphthona foudrasi Jacoby}

Aphthona foudrasi Jacoby, 1885, Zool. Soc. Lond., Proc. 1885: 729 (Japan: Oyama; BM).-Chen, 1934, Sinensia 5: 364, 369 (China, Tonkin, Japan).-Chûjô, 1937, Nat. Hist. Soc. Formosa, Trans. 27:120, 121 (Honshu; China, Tonkin).-Chûjô \& Kimoto, 1961, Pac. Ins. 3 (1): 172 (Honshu, Kyushu; China, Tonkin).-Gressitt \& Kimoto, 1963, Pac. Ins. Mon. 1B: 867, 868 (Japan, S. China, N. Vietnam).

Distribution: Japan (Hokkaido, Honshu, Kyushu), S. China, N. Vietnam.

Fukuoka: Sangun-zan (1 ex., 10. May. 1931, K. Yasumatsu leg.). Yamanashi : Obinayama in Kofu City (1 ex., 28. July. 1956, H. Kamiya leg.). Hokkaido: Ashoro in Tokachi (2 exs., 23. May. 1957, M. Takahashi leg).

IIosts: Euphorbia pseudochamaesyce; Euphorbia supina; Phyllanthus Urinaria (after Chûjô \& Kimoto, 1961).

\section{Aphthona strigosa Baly}

Aphthona strigosa Baly, 1874, Ent. Soc. Lond., Trans. 1874: 197 (Japan: Nagasaki; BM).-Chûjô, 1937, Nat. Hist. Soc. Formosa, Trans. 27:120, 121 (Kyushu).Chûjû \& Kimoto, 1961, Pac. Ins. 3 (1) : 173 (Japan, China, Formosa, Indo-China, Flores).-Gressitt \& Kimoto, 1963, Pac. Ins. Mon. 1B: 865, 870 (Japan, China, N. Vietnam).

Distribution: Flores, Indo-China, Taiwan, China, Japan (Honshu, Hachijo-jima, Shikoku, Kyushu, Tsushima).

Fukuoka: Mt. Inunaki; Shikanoshima in Kasuya-gun; Sarakura in Yahata City; Shirashima in Wakamatsu City; Kora-san in Kurume City; Tachibana-yama and Hirao in Fukuoka City; Kamihirokawa-mura in Yame-gun; Sengoku in Kurate-gun; Mt. Fukuchi; Mt. Hiko; Mt. Wakasugi. Miyazaki: Miyazaki City ; Aoidake; Mt. Osuzu. Kagoshima: Sata-misaki. Kumamoto: Tatsuta-yama in Kumamoto City. Kochi: Oki Is.; Mt. Sasa in Hata-gun; Jinzenji in Kochi City; Makiyama-mura in Kami-gun; Kuroson. Tokushima: Ishidate-yama. Kanagawa: Yugawara.

Host: Mallotus japonicus (after Châjo \& Kịmoto, 1961). 


\section{Aphthona formosana Chen}

Aphthona formosana Chen, 1934, Soc. Ent. France, Ann. 103: 179 (Formosa).-Chen, 1937, Nat. Hist. Soc. Formosa, Trans. 27 : 120, 122 (Sakishima group ; Formosa). -Chûjô \& Kimoto, 1961, Pac. Ins. 3 (1): 172 (Formosa, Ryukyu Is., Japan).

Aphthona varipes: Chûjô, 1958, Kagawa Univ., Mem. Fac. Lib. Arts. \& Educ. 2 (64): 10 (Loochoos: Sakiyama in Okinawa).

Aphthona formosana yakuana Nakane, 1958, Saikyo Univ., Sci. Rep. 2 (5): A313, fig. 35 (Japan: Kosugidani and Miyanoura in Yakushima).

Aphthona splendens?: Nakane \& Kimoto, 1961, Osaka Mus. Nat. Hist., Bull. 13: 78 (Amami Oshima, Tokara Is.).

Distribution: Taiwan, Ryukyu Is. (Iriomote, Ishigaki, Okinawa, Amami-Oshima, Tokara), Japan (Kyushu, Yakushima).

Sakishima group: Natayama in Iriomote Is.; Kainan in Ishigaki Is. Okinawa group: Mt. Yonaha, Chijuka in Okinawa Is. Amami group: Santaro-toge, Shinokawa, Shinmura, Koniya, Akatsuchiyama in Amami-Oshima. Tokara group: Nakanoshima. Miyazaki: Kiyotake in Miyazaki-gun (3 exs., 6. Aug. 1954, T. Ilidaka leg.). Kagoshima: Sata-misaki (1 ex., 29. May. 1953, S. Kimoto leg.).

Host: Mallotus japonicus (after Chûjô \& Kimoto, 1961).

\section{Aphthona perminuta Baly}

Aphthona pygmaea Baly, 1874 (nec Kutschera, 1861), Ent. Soc. Lond., Trans. 1874 : 198 (Japan: Nagasaki; BM).

Aphthona perminuta Baly, 1875, Col. Heft. 14: 213 (new name for A. pygmaea Baly). -Chûjô, 1937, Nat. Hist. Soc. Formosa, Trans. 27 : 120, 123 (Honshu, Kyushu).Chûjô \& Kimoto, 1961, Pac. Ins. 3 (1) : 173 (Japan, Ryukyu, S. Saghalien, China, Formosa, Indo-China).

Aphthona semiviridis Jacoby, 1885, Zool. Soc. Lond., Proc. 1885: 730 (Japan; BM).Chûjo, 1937, Nat. Hist. Soc. Formosa, Trans. 27 : 120, 122 (S. Saghalin, Japan).

Aphthona varipes: Yamamoto, 1953, Hyogo Seibutsu 2 (3): 6 (Japan: Kaibara in Hyogo Pref.).

Distribution: Japan (Hokkaido, Honshu, Sado I., Shikoku, Kyushu, Tsushima), S. Saghalien.

Fukuoka: Mt. Wakasugi ; Magaribuchi in Sawara-gun; Shirashima in Wakamatsu City; Mt. Hiko; Mt. Fukuchi; Mt. Tachibana and Hirao in Fukuoka City; Mt. Sefuri; Mt. Inunaki. Oita: Mt. Sobo. Ehime: Omogo-kei. Tokushima: Bizan in Tokushima City; Jinryomura in Myosai-gun; Nakatsu-yama. Kochi: Sako-mura in Kami-gun; Kashiwa Is.; Mt. Sasa in Hata-gun; Mt. Kuishi ; Makiyama-mura in Kami-gun ; Kajigamori in Nagaoka-gun ; Kuroson ; Ashizuri-misaki ; Jinzenji in Kochi City. Okayama: Kamo-cho in Tomata-gun. Tottori: Hoki-Daisen; Mt. Naki. Wakayama: Koyasan. Nara: Mt. Yoshino; Mt. Kasuga. Kyoto: Ushio. Ishikawa: Mt. Hakusan. Nagano: Shirahone; Asama-Onsen; Wada-toge; Karuizawa ; Shimashima; Omachi City; Utsukushigahara. Yamanashi: Masutomi in Kofu City. Kanagawa: Yugawara. Tokyo: Mt. Takao. Tochigi: Nikko. Aomori: Yunomata in Shimokita Pen. Hokkaido: Engaru in Abashiri; Nukabira and Ashoro in Tokachi; Nibushi in Akan Prov.

Hosts: Albizzịa Julibrissin; Edgeworthia papyrifera; Fagus crenata (after Chûjô \& 
Kimoto, 1961).

\section{Aphthona nigrita (Ohno) New Combination}

Trachyaphthona nigrita Ohno, 1961 (Feb.), Toyo Univ., Bull. Dept. Lib. \& Arts 2 : 74, 77 (Yakushima: Isso, Ambo, Miyanoura; Amami-Oshima: Yuwan, Gusuku; Онио).

Trachyaphthona nigrita maebarai Ohno, 1961, t. c., 74, 79 (Sata-misaki; OnNo). New Synonymy

Zipangia picea Nakane \& Kimoto, 1961 (March), Osaka Museum, Nat. Hist., Bull. 13: 76 (Tokara Is.: Nakanoshima; OMNH). New Synonymy

Aphthona shibatai Chûjô, 1961 (Oct.), Ent. Lab. Univ. Osaka Pref., Pub. 6: 88 (AmamiOshima: Ikari, Hatsuno; CHuso). New Synonymy

Distribution: Japan (Kyushu, Yakushima), Ryukyu Is. (Tokara, Amami-Oshima).

Kagoshima: Sata-misaki (36 exs., 25-30, May. 1953, T. Yoshida, I. Hiura \& S. Kimoto leg.).

Host: Paederia scandens (after Ohno, 1961).

\section{Genus Trachyaphthona Heikertinger}

Trachyaphthona Heikertinger, 1924, Kol. Rundsch. 11 (1-2) : 34 ; 1925, t. c., (3-4): 52 (type : Aphthona sordida Baly, 1874; Japan).-Chûjô, 1935, Nat. Hist. Soc. Formosa, Trans. 25 : 357 ; 1936, op. cit., 26 : 124.-Ohno, 1961, Toyo Univ., Bull. Dept. Lib. Arts 2: 73 (part).-Gressitt \& Kimoto, 1963, Pac. Ins. Mon. 1B: 747, 871 (part).

\section{Trachyaphthona sordida (Baly) (Fig. 3)}

Aphthona sordida Baly, 1874, Ent. Soc. Lond., Trans. 1874: 197 (Japan : Nagasaki; $\mathrm{BM})$.

Trachyaphthona sordida: Chûjô, 1937, Nat. Hist. Soc. Formosa, Trans. 27 : 124 (Honshu, Kyushu).-Chûjô \& Kimoto, 1961, Pac. Ins. 3 (1) : 193 (Japan).-Ohno, 1961, Toyo Univ., Bull. Dept. Lib. Arts 2: 75 (Hokkaido, Honshu, Shikoku, Kyushu, Iki, Tsushima).-Gressitt \& Kimoto, 1963, Pac. Ins. Mon. 1B : 871, 872 (Japan, S. China)

Piceous; basal joints of antennae, tibiae and tarsi paler than the others; length $2.0-2.2 \mathrm{~mm}$.

Distribution: Japan (Hokkaido, IIonshu, Shikoku, Kyushu, Iki, Tsushima, Yakushima), S. China.

Fukuoka: Mt. Fukuchi; Mt. Hiko; Mt. Kora in Kurume City; Magaribuchi in Sawara-gun; Hirao in Fukuoka City; Mt. Wakasugi; Ino in Kasuya-gun. Oita: Mt. Sobo. Kagoshima: Sata-misaki. Tokushima: Kamiyama-machi in Myosai-gun. Kochi : Jinzenji in Kochi City. Tokyo: Mt. Takao.

Host : Paederia scandens (after Chûjô \& Kimoto, 1961).

\section{Genus Batophila Foudras}

Batophila Foud., 1860, Soc, Linn Lỵon, $\Lambda$ nn. (n. s.) 6: 116, 378 (type : Galeruca rubi 


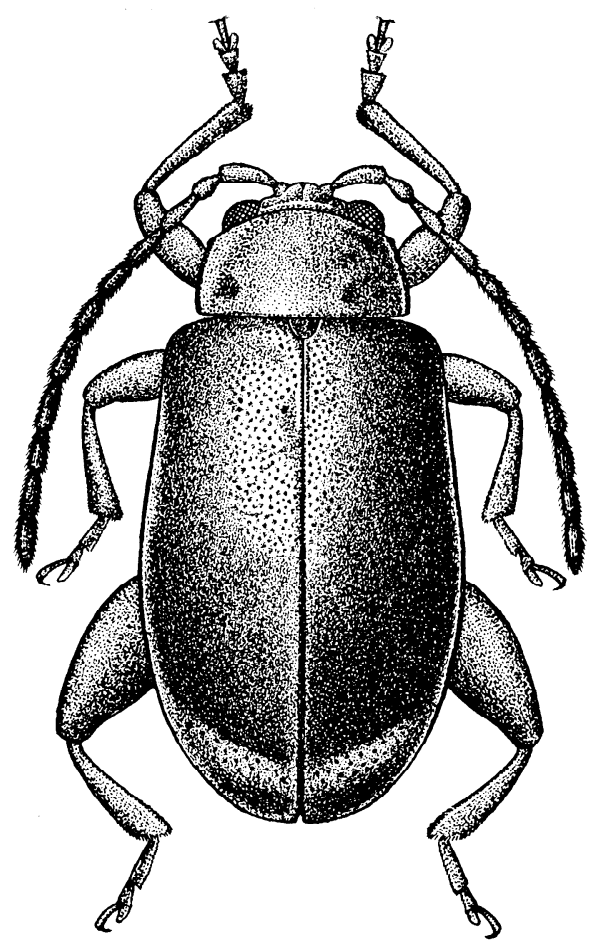

Fig. 3. Trachyaphthona sordida (Baly).

Paykul; Europe).-Heikertinger, 1921, Kol. Rundsch. 9 : 87 ; 1924, loc. cit. 11 (12) : 37 ; 1925, loc. cit. 11 (3-4): 52.-Chen, 1933, Sinensia 3: 228.-Chûjô, 1935, Nat. Hist. Soc. Formosa, Trans. 25 : 357.-Chen, 1936, Sinensia 7 (6): 639.-Chûjô, 1937, Nat. Hist. Soc. Formosa, Trans. 27: 51.-Heikertinger, 1948, Kol. Rundsch. 31 : 50 ; 1950, loc. cit. 31 (4-6): 125.-Gressitt \& Kimoto, 1963, Pac. Ins. Mon. 1B : 747, 875.

\section{Key to Japanese species of Batophila}

Punctures of pronotum large, and closely and distinctly impressed, and their interstices distinctly shagreened; dorsal surface blackish, in many cases with slight aeneous or greenish or bluish luster; ventral surface black, legs reddish brown, in some cases femora, especially posterior one, much darker; antennae reddish brown, apical joints somewhat infuscate in many cases; aedeagus subparallelsided or slightly narrowed anteriorly; length $1.6-2.0 \mathrm{~mm}$ acutangula

Punctures of pronotum much smaller, and more coarsely and finely impressed, and their interstices less clearly shagreened, comparing with the preceding species; black with cupreous luster on dorsal surface; legs reddish brown with posterior femora blackish; antennae reddish brown with first joint (except basal and apical 
parts) and apical joints more or less infuscate; aedeagus narrowed in middle; length $1.5-1.8 \mathrm{~mm}$

latissima

\section{Batophila acutangula Heikertinger (Figs. 4b-g)}

Batophila acutangula Heikertinger, 1921, Kol. Rundschau, 9: 91, 96 (E. Siberia); 1948, op. cit. 31 (1-3) : 53 (Amur, Ussuri ; Kiangsi).-Chûjô \& Shirôzu, 1955, Sieboldia, Fukuoka 1 (3): 237 (Japan: Kosugidani in Yaku-shima).-Chûjô \& Kimoto, 1961, Pac. Ins. 3 (1) : 175 (E. Siberia, China, Formosa, Japan).-Gressitt \& Kimoto, 1963, Pac. Ins. Mon. 1B: 875, 876 (E. Siberia, E. China, Taiwan, Japan).

Batophila yangweii Chen, 1933, Sinensia 3 (9): 250 (China).-Chûjô, 1935, Umeno Ent. Lab., Bull. 3: 13 (Japan: Mt. Hiko in Fukuoka Pref.).-Heikertinger, 1948, Kol. Rundsch. 31 (1-3): 53 (synonymized).

Batophila acutangula subsp. kamikochiana Nakane, 1958, Saikyo Univ., Sci. Rep. 2 (5): A313, fig. 34 (Japan: Kamikochi and Shimashima in Nagano Pref.; Nakane). -Châjô \& Kimoto, 1961, Pac. Ins. 3 (1) : 176 (Honshu).

Batophila acutangula subsp. kamikochiana Nakane f. hira Nakane, 1958, t. c., fig. 33 (Japan: Hira in Shiga Pref.; Nakane). Batophila acutangula subsp. omogo Nakane, 1958, $\boldsymbol{t}$. $\boldsymbol{c}$., fig. 32 (Japan: Omogo and Omogo-kei in Ehime Pref.; NaKane).Chûjô \& Kimoto, 1961, Pac. Ins. 3 (1) : 176 (Shikoku). New Synonymy

Batophila acutangula subsp. yakuensis Nakane, 1958, t. c., fig. 31 (Japan: Kosugidani, Miyanoura and Kurio in Yakushima; NAKANE).-Chûjô \& Kimoto, 1961, Pac. Ins. 3 (1): 176 (Yakushima). New Synonymy

Nakane (1958) described three subspecies and onc form bascd on materials from Yakushima, Omogo, Hira and Kamikochi. According to my studies, the species seems to be separable into three races in Japanese fauna.

The first race distributes in Yakushima, Kyushu (on rather high elevation), Shikoku (on rather high elevation) and southern part of Kinki District of Honshu. This race is characterized in having almost the straight lateral margins of pronotum and subquadrate or feebly rounded apex of aedeagus. Nakane (1958) described two subspecies based on the specimens from Yakushima and Omogo, and named them as yakuensis and omogo respectively. According to my studies the specimens taken from Mt. Hiko show the intermediate form between omogo and yakuensis. On the other hand, the specimens from Mt. Sobo show more affinity with yakuensis. I recognize that those two subspecies belong to the same race. The specimens taken from Mt. Koya (female specimens only) show distinct affinity with omogo.

The second race distributes in the northern part of Kinki to Hokkaido (on low elevation). The race is characterized in having rather short pronotum with rounded lateral margins, and in having distinctly pointed apex of aedeagus. The type may prove to represent a distinct species.

The third race is occurring in disticts of rather high clevation in Hokkaido. Unfortunately I could not see any male specimens. It is 


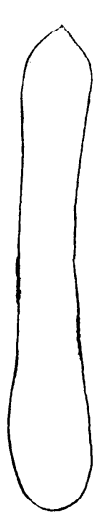

a

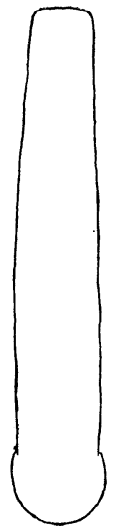

$\mathrm{b}$

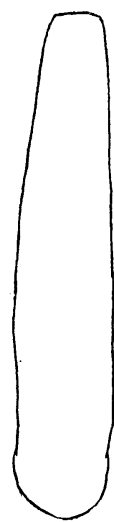

C

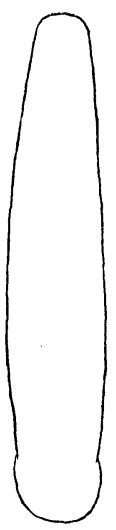

d

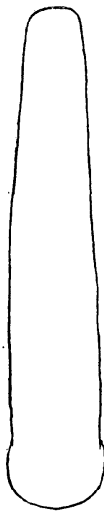

e

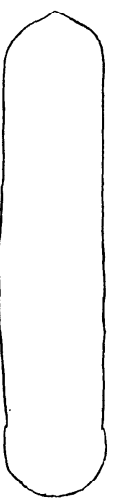

f

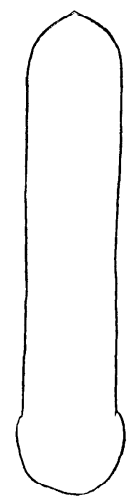

$\mathrm{g}$

Fig. 4. Male genitalia: a, Batophila latissima Chûjô ; a-g, B. acutangula Heikerginger (b, Mt. Sobo, c, Mt. Hiko, d, Omogo-kei, e, Makiyamamura, f, Masutomi, g, Karuizawa).

intersting that the female specimens of the race show more affinity with the first type than the second one.

Distribution: Siberia, China, Japan (Hakkaido, Honshu, Shikoku, Kyushu, Yakushima), Taiwan.

Fukuoka: Mt. Hiko. Oita: Mt. Sobo. Ehime: Omogo-kei; Nishigoyo in Mt. Ishizuchi, Kochi: Makiyama-mura in Kami-gun. Wakayama: Koyasan. Nagano: Karuizawa; Shimashima; Shirahone. Yamanashi: Masutomi. Hokkaido: Aizankei; Asahidake at Mt. Daisetsu; Engaru in Abashiri; Kuccharo in Akan Prov.

\section{Batophila latissima Chûjô (Fig. 4a)}

Batophila latissima Chûjô, 1957, Kontyû 25 (1): 17 (Loochoos: Sutaru-toge, Shinmura, Higashinakama and Yuwan in Amami-Oshima; CHuso).-Chûjô \& Kimoto, 1961, Pac. Ins. 3 (1) : 176 (Ryukyu Is.).

Distribution: Ryukyu Is. (Amami-Oshima).

\section{Genus Horaia Chûjô}

Horaia Chûjo, 1935, Nat. Hist. Soc. Formosa, Trans. 25: 357; 1937, op. cit. $27: 55$ (type: Horaia nigra Chûjô, 1937, Formosa).-Chûjô \& Ohno, 1961, Kagawa Univ., Mem. Fac. Lib. Arts \& Educ. 2 (106): 1.

\section{Key to Japanese species of Horaia (largely after Chûjô \& Ohno, 1961)}

1. Frontal tubercles separated from each other by an inter-antennal carina...... 2 Frontal tubercles separated from each other by a longitudinal sulcus; reddish 
brown with head, six or seven apical joints of antennae and legs usually

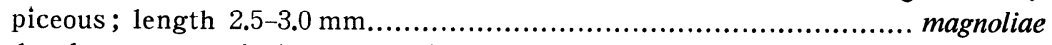

2. Body above not entirely reddish brown..............................................

Body above entirely reddish brown, with antennac yellowish brown; body beneath reddish brown; legs yellowish brown with posterior femora and tibiae reddish brown; length $2.5 \mathrm{~mm}$ fulva

3. Color shining black, with head, anterior corner of pronotum, prosternum, basal and apical parts of abdomen, and scutellum more or less piceous; antennae and legs (hind femora and each coxa excepted) yellowish brown; longitudinal raised area of head without any punctures on its surface; pronotum almost parallel-sided; not narrowed anteriorly; sides of mesosternal process slightly sinuate on its median part; length $2.0-2.5 \mathrm{~mm}$. minor

Color shining reddish brown; two or three apical joints of antennae, metathorax; hind femora and tibiae excepting basal part of the latter, and lateral area of elytra broadly, including elytral epipleurae, more or less piceous to black, and four anterior legs and antennae yellowish brown; longitudinal raised area of head with a pair of rather large punctures on its antero-lateral portion; pronotum slightly narrowed anteriorly; sides of mesosternal process nearly straight; length $2.0-2.5 \mathrm{~mm}$ esakii

\section{Horaia magnoliae Chûjô \& Ohno}

Horaia magnoliae Chûjo \& Ohno, 1961, Kagawa Univ., Mem. Fac. Lib. Arts \& Educ. 2 (106) : 2 (Mt. Izugatake in Saitama Pref., Mt. Scnaka-aburi in Fukushima Pref., Mt. Ohtaka, Kasayama in Saitama Pref., Mt. Hiko in Fukuoka Pref., Kurokawa in Niigata Pref., Morioka City in Iwate Pref., Mt. Myogi-san in Gumma Pref.; OnNo).

Distribution: Japan (Honshu, Kyushu).

A part of the type series is deposited in the Entomological Laboratory of Kyushu University.

Host : Magnolia obovata (after Chûjô \& Ohno, 1961).

\section{Horaia fulva Chûjô}

Horaia fulva Chûjô, 1937, Nat. Hist. Soc. Formosa, Trans. 27 : 58 (Formosa).-Chûjô \& Ohno, 1961, Kagawa Univ., Mem. Fac. Lib. Arts \& Educ. 2 (106): 2 (Formosa).

This is the first record of the species from Japan.

Distribution: Taiwan, Ryukyu Is. (Ishigaki).

Sakishima group: Ishigaki Is. (3 exs., 1-30. Dec. 1952, G. E. Bohart leg.).

\section{Horaia minor Chûjô}

Horaia minor Chûjô, 1937, Nat. Hist. Soc. Formosa, Trans. $27: 7$ (Formosa).-Chûjô \& Ohno, 1961, Kagawa Univ., Mem. Fac. Lib. Arts \& Educ. 2 (106): 2, 7 (Gusuku in Amami-Oshima).

Distribution: Taiwan, Ryukyu Is. (Amami-Oshima). 
Host : Piper Futokadzura (after Chûjô \& Ohno, 1961).

\section{Horaia esakii Chûjô \& Ohno}

Horaia esakii Chûjô \& Ohno, 1961, Kagawa Univ., Mem. Fac. Lib. Arts \& Educ. 2 (106) : 2, 5 (Nachi in Wakayama Pref., Okinoshima in Kochi Pref.; OHNo).

Distribution: Japan (Honshu, Shikoku).

A part of the type series is deposited in the Entomological Laboratory of Kyushu University.

Host : Piper Futokadzura (after Chûjô \& Ohno, 1961).

\section{Genus Aphthonomorpha Chen}

Aphthonomorpha Chen, 1935, Sinensia 5 (3-4): 357 (type : Crepidodera collaris Baly, 1887 ; China, Japan); 1936, op. cit. 7 (6): 639.-Gressitt \& Kimoto, 1963, Pac. Ins Mon. 1B: $747,877$.

\section{Aphthonomorpha collaris (Baly) (Fig. 5)}

Crepidodera collaris Baly, 1877, Ent. Soc. Lond., Trans. 1877 : 161 (China; BM). Aphthonomorpha collaris: Chûjô, 1937, Nat. Hist. Soc. Formosa, Trans. 4 (4): 59 (Japan: Koritorigawa in Tokushima Pref., Omogo Valley in Ehime Pref., Kaibara in Hyogo Pref.).-Chûjô \& Kimoto, 1961, Pac. Ins. 3(1): 173 (IndoChina, China, Formosa, Japan).-Gressitt \& Kimoto, 1963, Pac. Ins. Mon. 1B : 877 (S. China, N. Vietnam, Taiwan).

Head and prothorax reddish brown; elytra shining black; antennae black with three basal joints yellowish brown; fourth and fifth piceous; body beneath black; legs dark yellowish brown or piceous with posterior femora piceous or black; length $2.0-2.5 \mathrm{~mm}$.

Distribution: Indo-China, China, Taiwan, Japan (Shikoku, Kyushu).

Fukuoka: Mt. Hiko; Mt. Fukuchi. Kochi : Makiyama-mura in Kami-gun; Kuroson. Okayama: Kamo-cho in Tomatagun. Wakayama: Koya-san.

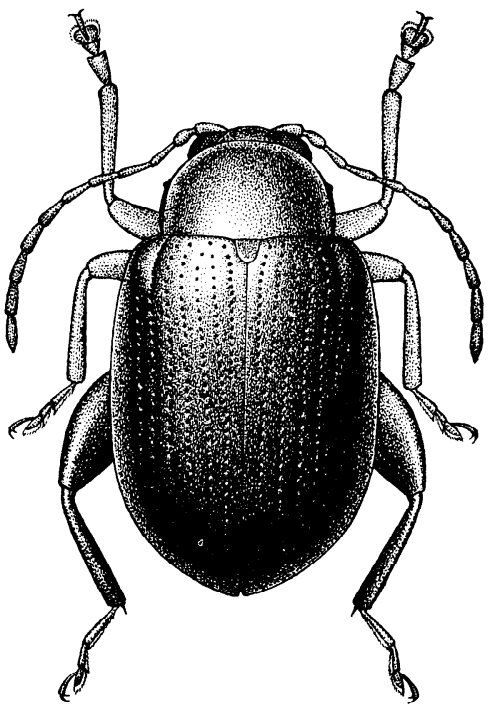

Fig. 5. Aphthonomorpha collaris (Baly).

\section{Genus Manobidia Chen}

Manobidia Chen, 1934, Sinensia 5 (3-4): 233, 358 (type: M. antennata Chen; Tonkin); 1936, op. cit. 7 (6) : 639.-Gressitt \& Kimoto, 1963, Pac. Ins. Mon. 1B : 747, 877. 


\section{Key to Japanese species of Manobidia}

Yellowish brown; elytra and legs slightly paler than the other parts in coloration; length $1.5 \mathrm{~mm}$

fulva

Black; antennae black with five basal joints yellowish brown; legs dark reddish brown with posterior femora blackish; length 1.5-2.0. nipponica

\section{Manobida fulva (Chûjô) New Combination}

Aphthonomorpha fulva Chûjô, 1957, Kontyû 25 (1): 16 (Loochoos: Sutaru-togo in Amami-Oshima; Choso).-Chûjô \& Kimoto, 1961, Pac. Ins. 3 (1): 174 (Ryukyu Is.).

Distribution: Ryukyu Is. (Amami-Oshima).

Amami group: Shinmura Akatsuchiyama in $\Lambda$ mami-Oshima (1 ex., 19. July. 1955, T. Shirózu leg.).

\section{Manobidia nipponica Chûjô}

Manobidia nipponica Chû́jô, 1959, Kagawa Univ., Mem. Fac. Lib. Arts \& Educ. 2 (81): 11 (Japan: Mt. Hiko in Fukuoka Pref., Mt. Sasahata in Kochi Pref., Valley Omogo-kei in Ehime Pref.; Chuso).-Chûjô \& Kimoto, 1961, Pac. Ins. 3 (1) : 185 (Japan).-Gressitt \& Kimoto, 1963, Pac. Ins. Mon. 1B : 877, 878 (Japan, China).

Distribution: Japan (Shikoku, Kyushu).

A part of the type series is deposited in the Entomological Laboratory of Kyushu University.

\section{Genus Liprus Motschulsky}

Liprus Motsch., 1860, Etud. Ent. 9: 26 (type: L. punctatostriatus Mots.=Diabrotica rufotestacea Mots. $=$ Crepidodera (Crepidomorpha) carinulata Fleish.; Janan).-Chûjo \& Kimoto, 1960, Niponius, Takamatsu 1 (4) : 8.-Gressitt \& Kimoto, 1963, Pac. Ins. Mon. 1B : 747, 878.

Crepidomorpha Fleischer, 1916, Wiener Ent. Ztg. 35: 222 (type: Crepidodera (Crepidomorpha) carinulata Fleischer; as a subgenus of Crepidodera).-Heikertinger, 1923, Wiener Ent. Ztg. 40: 136, 139; 1924, Kol. Rundsch. 11 (1-2): 40; 1925, op. cit. 11 (3-4): 52.-Chûjô, 1935, Nat. Hist. Soc. Formosa, Trans. 25: 357; 1936, op. cit. 26 : 19.-Heikertinger, 1948, Kol. Rundsch. 31 (1-3): 44.

\section{Liprus punctatostriatus Motschulsky}

Liprus punctatostriatus Motsch., 1860, Etud. Ent. 9: 26 (Japan).-Chûjô, 1935, Nat. Hist. Soc. Formosa, Trans. 25 : 396, 398 (Japan).-Chûjô \& Kimoto, 1961, Pac. Ins. 3 (1) : 181 (Japan, Korea, China).-Gressitt \& Kimoto, 1963, Pac. Ins. Mon. 1B : 878, 880 (Japan, Korea, N. China).

Diabrotica rufotestacea Mots., 1866, Soc. Nat. Moscou, Bull. 39 (1) : 175 (Japan).

Crepidodera japonica Jacoby, 1885 (nec Baly, 1877), Zool. Soc. Lond., Proc. 1885: 723, 
754 (Nikko; BM).-Heikertinger, 1924, Kol. Rundsch, 12 (1-2): 40 (as a synonym of rufotestacea).

Crepidodera japanensis Schönfeldt, 1887, Cat. Col. Japan, 192 (new name for C. japonica Jac.).

Crepidodera (Crepidomorpha) carinulata Fleischer, 1916, Wien. Ent. Ztg. $35: 222$ (Japan).

Crepidomorpha rufotestacea: Heikertinger, 1948, Kol. Rundsch. 31 (1-3): 44 (Japan;

S. Kansu).

Head, antennae, prothorax, scutellum and legs black or piceous; elytra, mesoand metahorax, and abdomen reddish brown, but in some cases entirely blackish; length $4.5-5.2 \mathrm{~mm}$.

Distribution: Japan (Honshu, Shikoku, Kyushu), Korea, N. China.

Tokushima: Nakatsuyama (1 ex., 21. May. 1954, Nishioka leg.). Nagano: Karuizawa (1 ex., 7-14. July. 1959, K. Morimoto leg.); Shirahone (1 ex., 19. July. 1956, S. Kimoto leg.). Kanagawa: Mt. Takatori (1 ex., 2. May. 1951, M. Takahashi leg.). Iwate: Hachimantai (1 ex., 10. July. 1957, Y. Ikutani leg.).

\section{Genus Manobia Jacoby}

Manobia Jac., 1885, Mus. Civ. Genova, Ann. Ser. 2, 2 (22) : 73 (type: M. nigripennis Jac.; first species described).-Heikertinger, 1924, Kol. Rundsch. 11 (1-2): 46; 1925, op. cit., (3-4) : 52.-Maulik, 1926, Fauna Brit. Ind., Chrysom. \& Halt., 285, 407.-Chen, 1934, Sinensia $5(3-4): 234$, 381.-Chûjo, 1935, Nat. Hist. Soc. Formosa, Trans. $25: 356 ; 1936$, op. cit. $26: 20$. -Chen, 1934, Sinensia 5 (3-4): 234, 381.-Heikertinger, 1948, Kol. Rundsch. 31 (1-3) : 48.-Gressitt \& Kimoto, 1963, Pac. Ins. Mon. 1B : 747, 881.

\section{Key to Japanese species of Manobia}

1. Pronotum narrowed posteriorly; ante-basal transverse impression deep; dorsal surface reddish or yellowish brown 2

Pronotum not narrowed posterioly; ante-basal transvese impression rather obsoletely impressed; dorsal surface entirely shining black; antennae piceous with four basal joints paler; body beneath black; legs piceous to black with femora dark brown; length $1.2-1.5 \mathrm{~mm}$ parvula

2. Elytral punctation obsoletely impressed generally, and strongly so only on a transverse sulcated area situated just bchind sub-basal convex area; body shape robuster and sub-basal transverse impression stronger comparing with lewisi; reddish or yellowish brown; antennae reddish brown with first and second in most cases seventh, eighth and ninth also, piceous; length $1.5 \mathrm{~mm}$......gressitti

Elytral punctation rather strongly impressed but less strongly so on sub-basal and apical areas; reddish or yellowish brown; body beneath piceous; length $1.5 \mathrm{~mm}$ lewisi

\section{Manobia parvula (Baly)}

Crepidodera parvula Baly, 1874, Ent. Soc. Lond., Trans. 1874: 185 (Japan: Nagasa$\mathrm{ki} ; \mathrm{BM})$. 
Manobia parvula: Chûjo, 1936, Nat. Hist Soc. Formosa, Trans. 26:21, 422 (Kyushu, Sakishima group).-Heikertinger, 1948, Kol. Rundsch. 31 (1-3) : 48 (Kyushu, Loochoos).

Aphthonomorpha parvula: Chûjô \& Kimoto, 1961, Pac. Ins. 3 (1) : 174 (Japan, Ryukyu).

Distribution: Japan (Shikoku, Kyushu), Ryukyu Is. (Iriomote, Ishigaki, Tokara). Sakishima group: Ishigaki Is. (4 exs., 1-30. Dec. 1952, G. E. Bohart leg.). Tokara group: Nakanoshima (1 ex., 5. June. 1953, S. Miyamoto lcg.).

Kochi : Jinzenji in Kochi City (1 ex., 24. July. 1954, 1 ex., 9. Apr. 1955, K. Morimoto leg.).

\section{Manobia lewisi Jacoby}

Manobia lewisi Jacoby, 1885, Zool. Soc. Lond., Proc. 1885: 741 (Japan: Ichiuchi; BM).-Chûjô, 1936, Nat. Hist. Soc. Formosa, Trans. 26: 21, 24 (Kyushu, Sakishima group).-Heikertinger, 1948, Kol. Rundsch. 31 (1-3): 48 (Kyushu, Loochoos). -Nakane \& Kimoto, 1961, Kontyû 29 (2): 107 (notes on type).

Manobia formosana: Kimoto, 1957, Kontyû 25 (2) : 55 (Japan: Cape Sata in Kagoshima Pref.).-Chûjô \& Kimoto, 1961, Pac. Ins. 3 (1) : 185 (Kyushu).

It is possible that Manobia formosana is a synonym of this species. Unless I have a chance to compare with the Formosan spccimens, I do not want to treat it as a synonym of the species.

Distribution: Japan (Kyushu, Yakushima), Ryukyu Is. (Amami-Oshima).

\section{Manobia gressitti Nakane \& Kimoto (Fig. 6a)}

Manobia gressitti Nakane \& Kimoto, 1961, Kontyû 29 (2): 106 (Sonai in Iriomote Is., Miyako Is.; NIAS).

Distribution: Ryukyu Is. (Iriomote, Miyako).

\section{Genus Lipromela Chen}

Limpromela Chen, 1933, Soc. Ent. France, Bull. $38: 144$ (type: L. costata Chen, 1933, Japan; monobasic).-Chûjô, 1935, Nat Hist. Soc. Formosa, Trans. 25: 356.

\section{Key to Japanese species of Lipromela}

Length 2.7-3.8 mm; second joint of antennae subequal to third; interstices of elytral striae slightly costate on lateral area; yellowish brown; two or three apical joints of antennae, in some cases eleventh only, blackish; underside and posterior part of femora blackish okinawana

Length 2.3-2.4 $\mathrm{mm}$; second joint of antennae slightly shorter than third; interstices of elytral striae more distinctly costate; yellowish brown; two or three apical joints blackish; apical part of femora and underside in most cases blackish or dark brown minutissima 


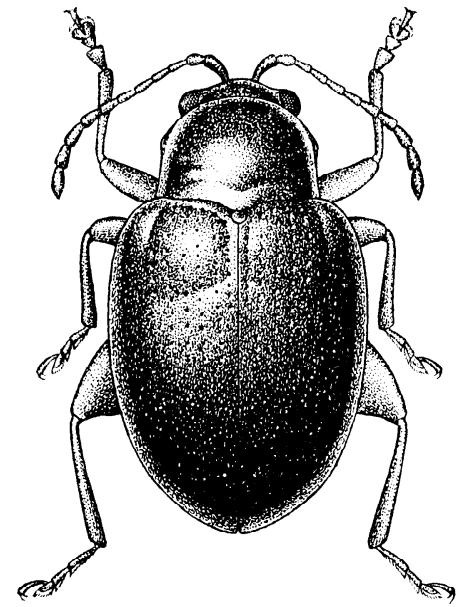

a

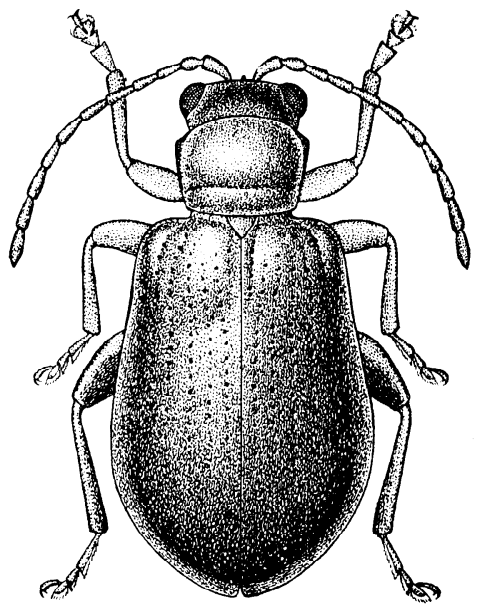

$\mathrm{b}$

Fig. 6. a, Monobia gressitti Nakane \& Kimoto; b, Lipromela minutissima (Pic).

\section{Lipromela minutissima (Pic) (Fig. 6b)}

Lema minutissima Pic, 1923, Mel. Exot. Ent. 11: 19 (Japan; PARIs).

Lipromela costata Chen, 1933, Soc. Ent. France, 38: 144 (Japan: Tokio; PARIs).Chûjô, 1936, Nat. Hist. Soc. Formosa, Trans. 26: 20 (Honshu).-Chûjo \& Kimoto, 1961, Pac. Ins. 3 (1): 181 (synonymized).

Lipromela minutissima: Chûjô \& Kimoto, 1961, Pac. Ins. 3 (1) : 181 (Honshu, Shikoku).

Distribution: Japan (Honshu, Shikoku, Kyushu).

Hiroshima: Sandankyo (2 exs., 31. May. 1957, K. Baba leg.). Nagano: Karuizawa (1 ex., 7-14. July. 1959, K. Morimoto leg.). Aomori: Yunomata in Shimokita Pen. (13 exs., 12. July. 1956, 1 ex., 27. July. 1956, K. Morimoto leg. ; 1 ex., 11. Aug. 1957, T. Saigusa leg.).

\section{Lipromela okinawana Chûjô}

Lipromela okinawana Chûjô, 1958, Kagawa Univ., Mem. Fac. Lib. Arts \& Educ. 2 (64): 12 (Loochoos: Sakiyama in Okinawa; CHUso).-Chûjo \& Kimoto, 1961, Pac. Ins. 3 (1): 181 (Ryukyu Is.).

Distribution: Ryukyu Is. (Okinawa).

\section{Genus Phygasia Dejean}

Phygasia Dejean, 1837, Cat. Col. ed. 3, 387 (type: Altica unicolor Olivier).-Maulik, 1926, Fauna India, Chrys. \& Halt., 186, 412.-Chen, 1933, Sinensia 3 (9): 221, 236 ; 1934, op. cit. 5 (3-4) : 234, 376.-Chûjo, 1935, Nat. Hist. Soc. Formosa, Trans. 25 : 355.-Chen, 1936, Sinensia 7 (6) : 643.-Chûjô, 1936, Nat. Hist. Soc. Formosa, Trans, 26 : 17,-Heikertinger, 1943, Kol, Rundsch, 31 (1-3) : 45,-Gressịt \& Ki- 
moto, 1963, Pac. Ins. Mon. 1B: 747, 882.

Scallodera IIarold, 1877, Dtsche Ent. Ztschr. $21: 356$ (type: Graptodera fulvipennis Baly ; Japan).-Heikertinger, 1924, Kol. Rundsch. 11 (1-2) : 38; 1925, op. cit. (34) : 52 .

Aldrisma Fairm., 1888, Kev. d'Ent. 7: 156 (type: A. externecostata Fairm., =P. fulvipennis Baly).

\section{Phygasia fulvipennis (Baly)}

Graptodera fulvipennis Baly, 1874, Ent. Soc. Lond., Trans. 1874: 193 (Japan: Nagasaki ; China; BM).

Phygasia fulvipennis: Chen, 1934, Sinensia 5 (3-4): 376 (China).-Chûjo, 1936, Nat. Hist. Soc. Formosa, Trans. 26: 17 (Honshu, Kyushu, Korea, China).-Heikertinger, 1948, Kol. Rundsch. 31 (1-3) : 46 (Japan, Korea, China).-Chûjô \& Kimoto, 1961, Pac. Ins. 3 (1) : 188 (Japan).-Gressitt \& Kimoto, 1963, Pac. Ins. Mon. 1B: 883, 884 (Japan, China).

Elytra brown; head, antennae, pronotum, scutellum and legs black; body beneath brown; length $5.0-6.0 \mathrm{~mm}$.

Distribution: China, Japan (Honshu, Awa-shima, Sado I., Shikoku, Kyushu, Tsushima).

Fukuoka: Shikanoshima in Kasuya-gun; Mt. Inunaki; Otani in Kokura City; Fukuoka City. Kagoshima: Sata-misaki. Nagano: Asama-Onsen.

Hosts: Cynanchum macroanthum var. Dickinsii; Metaplexis japonica ; Paederia scandens (after Chûjô \& Kimoto, 1961).

\section{Genus Hermaeophaga Foudras}

Hermaeophaga Foudr., 1860, Soc. Linn. Lyon, Ann. (n. s.) 6: 147.-Chapuis, 1875, Gen. Col. 11 : 124, 125.-Weise, 1886, Ins. Deutschl. Col. 6 : 678; 1888, t. c., 849.Heikertinger, 1912, in Reitter, Fauna Germ. 4: 145, 159; 1924, Kol. Rundsch. 11 (1-2) : 39 ; 1925, t. c., (3-4) : 52.-Maulik, 1916, Fauna India, Chrysom. \& Halt., 96.-Chûjô, 1935, Nat. Hist. Soc. Formosa, Trans. 25 : 356 ; 1936, op. cit., 26 : 19. -Chen, 1936, Sinensia 7 (6) : 643.-Gressitt \& Kimoto, 1963, Pac. Ins. Mon. 1B : 747.

\section{Hermaeophaga adamsii Baly}

Hermaeophaga adamsii Baly, 1874, Ent Soc. Lond., Trans. 1874: 193 (Japan: Tsu Sima; BM).-Chûjo, 1936, Nat. Hist. Soc. Formosa, Trans. 26 : 19 (Kyushu, incl. Tsushima).-Chûjô \& Kimoto, 1961, Pac. Ins. 3 (1): 180 (Japan).

Body oblong-oval; shining black; antennae piceous to black with four basal joints brown; legs yellowish brown with posterior femora piceous or black; length 1.5$2.0 \mathrm{~mm}$.

Distribution: Japan (Honshu, Sado I., Shikoku, Kyushu, Tsushima).

Nagasaki: Mt. Kanmuri (1 ex., H. Kamiya leg.). Kochi : Jinzenji in Kochi City (1 ex., 24. July. 1954, K, Morimoto leg.). 


\section{Genus Ogloblinia Csiki}

Ochrosoma Ogloblin, 1930 (nec Herr.-Schaeff., 1854), Eos 6: 104 (type : Crepidodera nigripennis Motsch.; Ceylon, Burma).-Chen, 1934, Sinensia 5 (3-4): 234, 380 ; 1936, op. cit. 7 (6) : 642.

Ogloblinia Csiki, 1940, in Heikertinger \& Csiki, Col. Cat. 166: 280 (new name for Ochrosoma Ogloblin).-Gressitt \& Kimoto, 1963, Pac. Ins Mon. 1B: 748, 881.

Sphaeraltica Ohno, 1961, Toyo Univ., Bull. Dept. Lib. Arts 2: 84 (type : Graptodera flavicornis Baly, 1874 ; Japan). New Synonyny

\section{Key to Japaneses species of Ogloblinia}

1. Frontal tubercles feebly raised and not distinctly separated from vertex by a distinct furrow; dorsal surface bluish black, antennae dark reddish brown with two or three basal joints reddish brown; legs reddish brown with femora blackish; length $2.0-2.5 \mathrm{~mm}$ berberii

Frontal tubercles distinctly raised and distinctly separated from vertex by a deep furrow; dark reddish brown or blackish brown; antennae and legs yellowish brown, except posterior femora dark brown; length $1.5-2.0 \mathrm{~mm}$

flavicornis

\section{Ogloblinia berberii (Ohno) New Combination}

Sphaeraltica berberii Ohno, 1961, Toyo Univ., Bull. Dept. Lib. Arts 2: 85, 87 (Okumusashi-kogen in Saitama Pref.; Vicinity of Esumi in Wakayama Pref.; Yuyama in Kumamoto Pref.; Оноо).

Distribution: Japan (Honshu, Shikoku, Kyushu).

Tokusima: Jinryo-mura in Myosai-gun (1 ex., 26. July. 1953, I. Hiura leg.). Kochi : Makiyama-mura (1 ex., 2. Sept. 1954, K. Morimoto leg.). Hyogo: Mt. Maya (1 ex., 3. Sept. 1953, K. Morimoto leg.). NARA: Mt. Yoshino (1 ex., 18. May. 1953, K. Sawada leg.).

Host: Berberis Thunbergii DC (after Ohno, 1961).

\section{Ogloblinia flavicornis (Baly)}

Graptodera flavicornis Baly, 1874, Ent. Soc. Lond., Trans. 1874 : 192 (Japan: Nagasaki; BM).

Haltica flavicornis: Chûjo, 1936, Nat. Hist. Soc. Formosa, Trans. 26:24, 25 (Kyushu, Sakishima group).

Sphaeraltica flavicornis: Ohno, 1961, Toyo Univ., Bull. Dept. Lib. Arts 2: 85 (Honshu, Shikoku, Kyushu, Tsushima, Yakushima, Loochoos).

Ogloblinia flavicornis: Châjô \& Kimoto, 1961, Pac. Ins. 3 (1) : 187 (Japan, Ryukyu Is.).

Distribution: Japan (Honshu, Shikoku, Kyushu, Tsushima, Yakushima), Ryukyu Is. (Tokara, Amami-Oshima, Ishigaki, Iriomote).

Sakishima group: Ishigaki Is, Tokara group: Nakanoshima, 
Fukuoka: Sengoku in Kurate-gun; Shikanoshima in Kasuya-gun; Hirao in Fukuoka City; Ino in Kasuya-gun. Kagoshima: Sata-misaki; Kaimon-dake. Kochi: Oki Is. ; Jinjenji in Kochi City; Ashizuri-misaki.

Hosts: Stephania japonica; Cocculus trilobus DC (after Ohno, 1961).

\section{Genus Zipangia Heikertinger}

Zipangia Heikertinger, 1924, Kol. Rundsch. 11 (1-2): 39; 1925, op. cit. 11 (3-4): 52 (type: Haltica obscura Jacoby, 1885; Japan).-Chen, 1933, Sinensia 3: 221 (err. Jipangia) ; 1934, op. cit. 5 : 234, 388.-Chûjô, 1935, Nat. Hist. Soc. Formosa, Trans. 25: 356 ; 1936, op. cit. $26: 30$.-Chen, 1936, Sinensia 7 (6) : 644.

Trachyaphthona: Ohno, 1961, Toyo Univ., Bull. Dept. Lib. Arts 2: 73 (part; Zipangia synonymized).-Gressitt \& Kimoto, 1963, Pac. Ins. Mon. 1B : 718, 871 (part).

\section{Key to Japanese species of Zipangia}

Anterior corner of pronotum obliquely and broadly truncate, and hind corner rather distinctly produced laterally; entirely flavous, in many specimens from the Loochoos generally black or piceous, with antennae and legs, except darker posterior femora reddish brown; length $2.0-3.2 \mathrm{~mm}$ lewisi

Anterior corner of pronotum not so broadly truncate and hind corner not distinct1y produced laterally; piceous to black; antennae blackish with some basal joints flavous; legs flavous with posterior femora piceous to black; length 2.0$3.0 \mathrm{~mm}$ obscura

\section{Zipangia lewisi (Jacoby)}

Haltica lewisi Jacoby, 1885, Zool. Soc. Lond., Proc. 1885: 727 (Japan: Kashiwagi, Chiuzenji; BM).-Chûjô, 1936, Nat. Hist. Soc. Formosa, Trans. 26: 24, 25 (Honshu).

Trachyaphthona lewisi: Ohno, 1961, Toyo Univ., Bull. Dept. Lib. Arts 2: 75, 81 (Honshu, Shikoku, Kyushu).-Gressitt \& Kimoto, 1963, Pac. Ins. Mon. 1B: 872 (Japan, Ryukyu, China).

Trachyaphthona lewisi amamiana Ohno, 1961, t. c., 75, 83 (Amami-Oshima; Oнno). New Synonymy

Zipangia lewisi: Chûjô \& Kimoto, 1961, Pac. Ins. 3 (1) 193 (Japan, Ryukyu Is.).

Distribution: China, Japan (Honshu, Shikoku Kyushu), Ryukyu Is. (Amami-Oshima, Okinawa).

Okinawa group: Yonaha in Okinawa Is.

Fukuoka: Mt. Hiko; Mt. Fukuchi. Kumamoto: Mt. Ichifusa. Kagoshima: Sata-misaki. Oita: Mt. Sobo. Kochi: Mt. Sasa in Hata-gun; Kajigamori in Nagaoka-gun. Tokushima: Jinryo-mura in Myosai-gun. Okayama: Kamo-cho in Tomata-gun. Ishikawa: Hakusan. Nagano: Shirahone; Karuizawa. Tokyo: Mt. Takao. Tochigi : Nikko. Gumma: Shiroh Pass.

Hosts : Viburnum furcatum; Viburnum dilatatum (after Ohno, 1961).

\section{Zipangia obscura (Jacoby)}

Haltica obscura Jacoby, 1885, Zool. Soc, Lond., Proc, 1885: 726 (Japan: Yuyama; 
$\mathrm{BM})$.

Zipangia obscura: Chen, 1934, Sinensia 5: 388 (China, Tonkin, Japan).-Chûjô, 1936, Nat. Hist. Soc. Formosa, Trans. 26:30 (Honshu, Formosa).-Chûjô \& Kimoto, 1961, Pac. Ins. 3 (1): 193 (Japan).

Trachyaphthona obscura: Ohno, 1961, Toyo Univ., Bull. Dept. Lib. Arts 2: 75, 79 (Honshu, Shikoku, Kyushu, Iki, Tsushima; China, Formosa, Indo-China).-Gressitt \& Kimoto, 1961, Pac. Ins. Mon. 1B : 872 (Japan, S. China, N. Vietnam).

Distribution: Japan (Honshu, Shikoku, Kyushu, Iki, Tsushima), China, Taiwan, Indo-China.

Fukuoka: Mt. Hiko. Nagano: Karuizawa. Kanagawa: Yugawara. Tochigi: Nikko.

Hosts: Lonicera japonica L. gracilipes; Weigela japonica; Viburnum dilatatum, V. luzonica formosanum (after Ohno, 1961).

\section{Genus Zipanginia Ohno}

Zipanginia Ohno, 1962, Annot. Zool. Japon. 35 (1) : 23 (type: Graptodera picipes Baly, 1874 ; Japan).

\section{Key to Japanese species of Zipanginia (largely after Ohno, 1961)}

1. Body above dark piceous to black, with legs more or less piceous partly; extreme apex of each elytron more or less truncate; elytral epipleurae not reaching apex of elytra, but a little before the latter.

Body above entirely dark metallic green, with four anterior legs and posterior tibiae and tarsi entirely reddish brown; extreme apex of each elytron rounded; elytral epipleurae almost reaching apex of elytra; length $2.5 \mathrm{~mm}$... loochooana

2. Pronotum about $11 / 2$ times as broad as long, sides gently rounded; frons nearly smooth and impunctate; surface of elytral epipleurae nearly flat in their whole length; mesosternal process not distinctly narrowed posteriorly; length $2.0-2.2 \mathrm{~mm}$ picipes picipes

Pronotum about $11 / 3$ times as broad as long, sides straight and parallel; vertex and frons (except post-clypeus and frontal tubercles rather distinctly shagreened; surface of elytral epipleurae rather distinctly chanelled in their basal half; mesosternal process rather distinctly narrwed posteriorly; length $2.5 \mathrm{~mm}$ picipes katoi

\section{Zipanginia loochooana Ohno}

Aphthona nubila: Chûjo, 1958, Kagawa Univ., Mem. Fac. Lib. Arts \& Educ. 2 (64): 10 (Loochoos: Nakasone in Okinawa).-Chûjô \& Kimoto, 1961, Pac. Ins. 3 (1): 173 (Ryukyu Is.).

Zipanginia loochooana Ohno, 1962, Annot. Zool. Japon. 35 (1): 24, 27 (Yuwan in Amami-Oshima; Онко).

Distribution: Ryukyu Is. (Amami-Oshima, Okinawa).

The species recorded as Aphthona nubila by Chûjô (1958) should be corrected as Zipanginia loochooana Ohno which was described by a 
single female specimen.

\section{Zipanginia picipes (Baly)}

Graptodera picipes Baly, 1874, Ent. Soc. Lond., Trans. 1874: 191 (Japan: Nagasaki; $\mathrm{BM})$.

Haltica picipes: Chûjô, 1936, Nat. Hist. Soc. Formosa, Trans. 26: 24, 26 (Kyushu). Ogloblinia picipes: Chûjô \& Kimoto, 1961, Pac. Ins. 3 (1) : 188 (Japan).

Zipanginia picipes: Ohno, 1962, Annot. Zool. Japon. 35 (1): 24 (Honshu, Shikoku, Kyushu).

Distribution: Japan (Honshu, Shikoku Kyushu).

Fukuoka: Mt. Hiko (1 ex., 2. Aug. 1953, 1 ex., 26. July. 1954, S. Kimoto leg.; 7 exs., 15. May. 1955, K. Morimoto leg.; 1 ex., 16. July. 1954, H. Kamiya leg.; 1 ex., 1. Aug. 1954, T. Yoshida leg.). Oita: Mt. Sobo (1 ex., 25. July. 1955, II. Kamiya leg.).

Hosts: Elaeagnus pungens (after Chûjô \& Kimoto, 1961); Elaeagnus multiflora (after Takakura, 1955).

\section{Zipanginia picipes katoi Ohno}

Zipanginia picipes katoi Ohno, 1962, Annot. Zool. Japon. 35 (1) : 24, 26 (Manazuru in Kanagawa Pref.; OHNo).

This subspecies was described by a single female specimen which is very closely allied to the nominate subspecies. Unless more materials are available, it would be almost impossible to decide the status of the subspecies.

Distriburion: Japan (Honshu).

\section{Genus Aphthonaltica Heikertinger}

Aphthonaltica Heikertinger, 1924, Kol. Rundsch. 11 (1-2): 39; 1925, t. c. (3-4): 52.Chûjô, 1935, Nat. Hist. Soc. Formosa, Trans. $25: 356 ; 1936$, t. c., $26: 29 .-$ Chen, 1936, Sinensia 7 (6) : 645.-Gressitt \& Kimoto, 1963, Pac. Ins. Mon. 1B : 748.

\section{Aphthonaltica angustata (Baly)}

Graptodera angustata Baly, 1871, Ent. Soc. Lond., Trans. 1871: 191 (Japan : Nagasa$\mathrm{ki} ; \mathrm{BM})$.

Aphthonaltica angustata: Chûjô, 1936, Nat. Hist. Soc. Formosa, Trans. 26 : 29 (Honshu, Kyushu).-Chûjô \& Kimoto, 1961, Pac. Ins. 3 (1) : 173 (Japan).

Body oblong. Body above metallic greenish blue; antennae black with three or four basal joints yellowish brown; body beneath black; legs black, with tarsi dark reddish brown; length $2.0-3.0 \mathrm{~mm}$.

Distribution: Japan (Honshu, Sado I., Shikoku, Kyushu).

Fukuoka: Mt. Wakasugi; Mt. Hiko; Mt. Inunaki. Kochi: Jinzenji in Kochi City; Kuroson, Kyoto: Kibunne; Mt, Daimonji. Osaka: Ṃt, Mỵoken, Nara: Mt, 
Yoshino. Tochigi: Nikko. Kanagnwa: Yugawàra.

\section{Genus Altica Fabricius}

Altica Geoffroy, 1762, Hist. Ins. 1: 244 (nomen nudum).-Fabricius, 1775, Syst. Ent. 112 (type: Chrysomela oleracea L.).-Ohno, 1960, Toyo Univ., Bull. Dept. Lib. Arts 1: 77.-Gressitt \& Kimoto, 1963, Pac. Ins. Mon. 1B: 748, 886.

Haltica: Chapuis, 1875, Gen. Col. 11 : 59.-Heikertinger 1912, in Reitter, Fauna Germ., 1: 167 ; 1924, Kol. Rundsch. 11 : 39, fig. 7 ; 1925, op. cit. 11: 69.-Maulik, 1926, Fauna India, Chrysom. \& Halt., 418.-Chen, 1933, Sinensia 3: 214, 217, 221, figs. 3, 6c ; 1934, op. cit. 5 : 235, 390.-Chûjô, 1935, Nat. Hist. Soc. Formosa, Trans. 25 : 356 ; 1936, op. cit. $26: 21$.-Chen, 1936, Sinensia $7: 645$.

Graptodera Chevrolat, 1845, in d'Örbigny, Dict. Univ. d'Ilist. Nat. $6: 307$.

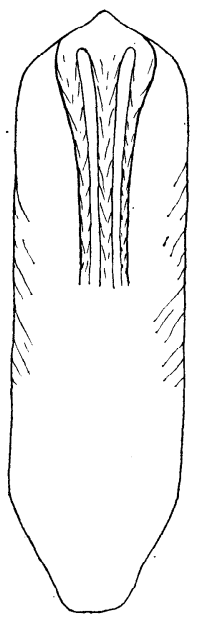

a
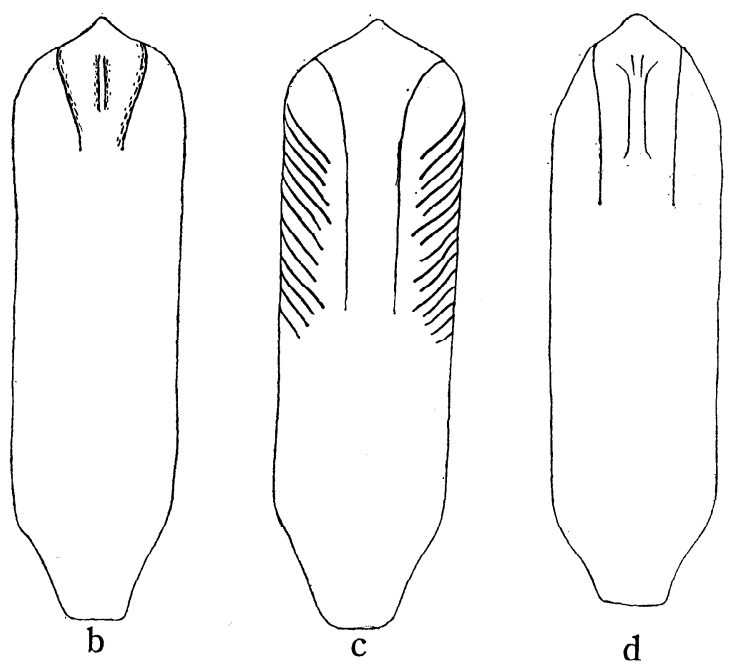

Fig. 7. a, Altica circaeae Ohno; b, A. himalayensis japonica Ohno; c, A. caerulescens (Baly); d, A. oleracea (Linnaeus).

\section{Key to Japanese species of Altica}

1. Elytra without distinct, sharp longitudinal ridge, but in some cases feebly costate.

Elytra with a sharp longitudinal ridge situated on the same level with humeri along lateral margin; dorsal surface finely shagreened and elytra obsoletely punctate; metallic greenish blue; length $4.5-5.6 \mathrm{~mm}$...... latericosta latericosta

2. Elytral punctation distinctly impressed.

Elytral punctation obsoletely impressed and interstices very finely shagreened; metallic green to greenish blue; length 4.0-5.5 mm........latericosta subcostata

3. Ante-basal transverse impression with a pair of short, lateral longitudinal impressions or foveae laterally, black with bluish or greenish luster; length $3,5-4,5 \mathrm{~mm}$ 
Ante-basal transverse impressinn without any short longitudinal impressions or foveae laterally

4. Surface of elytra smooth and shining................................................

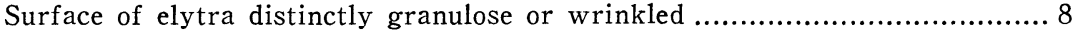

5. Third joint of antennac nearly equal to, or a little longer than, second........6 6

Third joint of antennae nearly twice as long as second; blackish blue to vio-

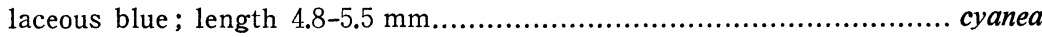

6. Ventral surface of aedeagus with a broad longitudinal sulcus or with a pair of longitudinal sulci.

Ventral surftce of aedeagus with three longitudinal sulci; blackish, violaceous, or greenish blue; length $3.0-4.0 \mathrm{~mm}$ circaeae

7. Large in size; punctation of elytra distinct; aedeagus: ventral surface of lateral area strongly declivitous and without any distinct oblique grooves; black with bluish luster; length $4.0-4.5 \mathrm{~mm}$

himalayensis japonica

Small in size; punctation of clytra much fincr than the preceding species; aedeagus: ventral surface of lateral area convex and with many distinct, deep oblique grooves; blackish blue; length $3.2-4.3 \mathrm{~mm}$ caerulescens

8. Aedeagus: apex triangularly produced, subparallel-sided and narrowed at apical area.

Aedeagus: apex rounded, not produced triangularly widest at subapical area; blue, greenish blue, or cupreous blue; lehgth $2.8-3.8 \mathrm{~mm}$ oleracea

9. Aedeagus: ventral surface with a pair of distinct sharp costae ................ 10

Aedeagus: ventral sufface without a pair of sharp, distinct costae, or with three or four feebly raise ones

10. Aedeagus: ventral surface with a pair of very sharp ridges which are gradually separated from each other from middle to apex; blackish blue with greenish luster; length $3.2-4.3 \mathrm{~mm}$ cirsicola

Aedeagus: ventral surface with a pair of rather bruntly raised costae and their insides distinctly grooved, and those costae running subparallelly ; blackish blue with greenish or cupreous luster; length $2.6-3.3 \mathrm{~mm}$

viridicyanea

11. Aedeagus: strongly curved dorsally in lateral view, three longitudinal sulci narrow, and narrower than their interstices; bluish black; length $3.0-3.8 \mathrm{~mm}$

kurosawai

Medeagus: obsoletely curved dorsally in lateral view, three longitudinal sulci wide, and wider than their interstices; blackish blue with or without slight greenish luster; length $3.5-4.0 \mathrm{~mm}$ fragariae

\section{Altica latericosta (Jacoby)}

Haltica latericosta Jacoby, 1885, Zool. Soc. Lond,, Proc. 1885: 726 (Sapporo ; BM).Chûjô, 1936, Nat. Hist. Soc. Formosa, Trans. 26: 25, 26 (Hokkaido, Honshu; China).

Altica latericosta: Ohno, 1960, Toyo Univ., Bull. Dept. Lib. Arts 1: 78, 79 (Hokkaido ; ? China).--Chûjô \& Kimoto, 1961, Pac. Ins. 3 (1) : 171 (Japan, China).-Gressitt \& Kimoto, 1963, Pac. Ins. Mon. 1B : 886, 891 (Japan, W. China).

Distribution: W. China, Japan (Hokkoido).

Hokkaido: Ashoro in Tokachi (3 exs., 24-31. Aug. 1959, K, Morimoto leg.).

Host : Salix sp. (after Chûjô \& Kịmoto, 1961). 


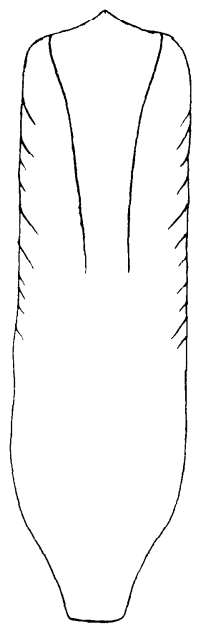

a

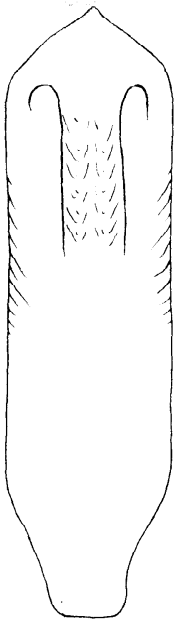

$\mathrm{b}$

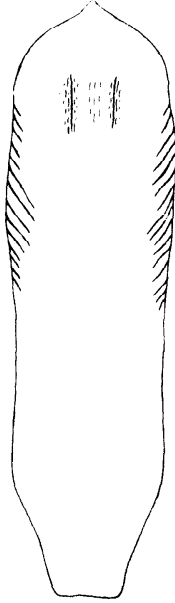

c

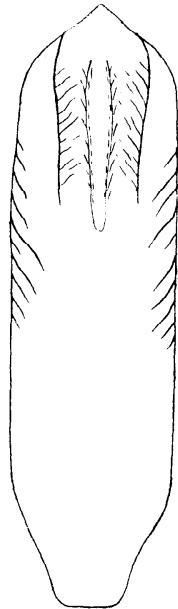

d

Fig. 8. a, Altica cirsicola Ohno; b, A. viridicyanea (Baly); c, A. kurosawai Ohno; d, A. fragariae (Nakane).

\section{Altica latericosta subcostata Ohno}

Haltica eruceae: Motschulsky, 1886, Soc. Imp. Nat. Moscou, Bull. 39 (1) : 175 (Japan).

Haltica quercetorum: Lewis, 1879, Cat. Col. Japanese Archipelago, 29 (Japan).

Haltica tamaricis: Heikertinger \& Csiki, 1939, Col. Cat. 166: 234 (Japan).

Altica latericosta subsp. subcostata Ohno, 1960, Toyo Univ., Bull. Dept. Lib. Arts 1: 80 (Takeoka in Kagoshima City, Ilitoyoshi in Kumamoto Prof., Nakamura in Kochi Pref., Ohkawara in Fukushima Pref., Mt. Chokai in Yamagata Pref.; OHNo).

Distribution: Japan (Honshu, Shikoku, Kyushu).

Fukuoka: Tashiro in Yame-gun. Oita: Mt. Sobo. Kochi: Makiyama in Kamigun; Jinzenji in Kochi City. Tokushima: Akuigawara in Tokushima City. Kyoto: Mt. Daihi.

Hosts: Salix spp. (after Chûjô \& Kimoto, 1961).

\section{Altica nipponica Ohno}

Altica nipponica Ohno, 1960, Toyo Univ., Bull. Dept. Lib. Arts 1:80, pl. 1, fig. V, p1. 2, fig. 8 (Mt. Yatsugatake in Nagano Pref., Mt. Hayachine in Iwate Pref., Vicinity of Towada Lake in Aomori Pref., Yunohara in Fukushima Pref., Nikko in Tochigi Pref.; Ouno).-Chûjô \& Kimoto, 1961, Pac. Ins. 3 (1): 171 (Honshu).

Distribution; Japan (Honshu).

Nagano: Shirahone; Karuizawa. Yamanashi: Masutomi. Tochigi: Nikko.

Host : Oenothera Lamarckiana (after Ohno, 1960). 


\section{Altica cyanea (Weber)}

Galleruca cyanea Weber, 1801, Observ. Ent. 1: 57 (Sumatra).

Haltica cyanea : Weise, 1922, Tijdschr. Ent. 65 : 109 (China, Java, Sumatra, Borneo, Singapore, Formosa, Luzon; Japan; Satsu, Osaka).-Maulik, 1926, Fauna India, Chrysom. \& Halt., 422 (India, Burma).-Chen, 1934, Sinensia 5 (3-4): 392, fig. 10 (China, Tonkin, Japan, Burma, Formosa Java, Sumatra, Borneo, Singapore).Chûjo, 1936, Nat. Hist. Soc. Formosa, Trans. 26 : 25, 28 (Honshu, Kyushu, Formosa, China, Indo-China, Burma, India, Java, Sumatra, Borneo).

Altica cyanea: Ohno, 1960, Toyo Univ., Bull. Lib. Arts 1: 79, 90 (Honshu, Shikoku, Kyushu, Yakushima, Loochoo ; Formosa, China, Indo-China, Queensland, Burma, Java, Sumatra, Borneo, Philippines, New Guinea).-Chûjô \& Kimoto, 1961, Pac. Ins. 3 (1) : 170 (India, Burma, Indo-China, Singapore, Sunda Is., China, Formosa, Philippines, New Guinea, Queensland, ? Asia Minor, Ryukyu Is., Japan).Gressitt \& Kimoto, 1963, Pac. Ins. Mon. 1B: 887, 889 (Sunda Is., Malaya, IndoChina, Japan, Taiwan, Philippines, New Guinea).

Distribution: Sunda Is., Malaya, India, Burma, Indo-China, China, Japan (Honshu, Shikoku, Kyushu, Yakushima), Ryukyu Is. (Tokara, Amami-Oshima, Okinawa, Iriomote), Taiwan, Philippines, New Guinea.

Sakishima group: Iriomote (after Nakane \& Kimoto, 1961). Amami group: Amami-Oshima (after Nakane \& Kimoto, 1961). Tokara group: Takarajima, Nakanoshima (after Nakane \& Kimoto, 1961).

Fukuoka: Ohorimachi in Fukuoka City; Kinbu in Sawara-gun; Mt. Wakasugi. Miyazaki: Aoshima. Kagoshima: Sata-misaki. Kochi: Jinzenji in Kochi City.

Hosts: Jussiaea prostrata; Ludwigia ovalis (after Ohno, 1960).

\section{Altica circaeae Ohno (Fig. 7a)}

Altica circaeae Ohno, 1960, Toyo Univ., Bull. Dept. Lib. Arts 1: 89, pl. f, figs. B, VI, 2 (Jinmuji in Kanagawa Pref. (type locality); Hokkaido, Honshu, Kyushu; Oıro).—Chûjô \& Kimoto, 1961, Pac. Ins. 3 (1): 170 (Japan).

Distribution: Japan (Hokkaido, Honshu, Kyushu).

Fukuoka: Mt. Hiko. Tottori: Mt. Naki.

Hosts: Circaea alpina; Circaea cordata ; Circaea erubescens (after Ohno, 1960).

\section{Altica himalayensis japonica Ohno (Fig. 7b)}

Altica himalayensis subsp. japonica Ohno, 1960, Toyo Univ., Bull. Dept. Lib. Arts 1: 92, pl. 1, figs. II, 4 (Mt. Chokai in Yamagata Pref., Mt. Ohtakine in Fukushima Pref., Isobe in Gumma Pref., Hanno in Saitama Pref., Tajimagahara in Saitama Pref., Fuji-Yoshida in Yamanashi Pref.; Orno).-Chûjô \& Kimoto, 1961, Pac. Ins. 3 (1) : 171 (Japan).

Distribution: Japan (Honshu, Shikoku, Kyushu).

Fukuoka: Tatara in Fukuoka City. Tokushima: Jinryo-mura in Myosai-gun. Okayama: Kamo-cho in Tomata-gun. Fukui : Takefu City.

Host : Geranium nepalense var. Thunbergii (after Ohno, 1960). 


\section{Altica caerulescens (Baly) (Fig. 7c)}

Graptodera caerulescens Baly, 1874, Ent. Soc. Lond., Trans. 1874 : 190 (Japan : Nagasaki, Tsushima; China; BM).

Haltica caerulescens: Maulik, 1926, Fauna India, Chrysom. \& Haltic., 421 (India, Japan, China).-Chûjô, 1936, Nat. Hist. Soc. Formosa, Trans. $26: 27$ (Japan, Loochoo, Formosa, China).

Altica caerulescens: Ohno, 1960, Toyo Univ., Bull. Dept. Lib. Arts 1: 79, 91 (Hokkaido?, Honshu, Sado I., Hachijo, Aogashima, Shikoku, Kyushu, Tsushima, Loochoo, Formosa, Korea, Manchuria, China, India).-Chûjo \& Kimoto, 1961, Pac. Ins. 3 (1): 170 (Japan, Ryukyu Is., Korea, Manchuria, China, Formora, India).-Gressitt \& Kimoto, 1963, Pac. Ins. Mon. 1B : 887, 888 (Japan, S. China, Korea, Ryukyu Is., Taiwan, India).

Distribution: India, Taiwan, S. China, Ryukyu Is. (Amami-Oshima, Okinawa, Miyako, Ishigaki), Japan (?Hokkaido, Honshu, Sado I., Hachijo, Mogashima, Shikoku, Kyushu, Tsushima).

Okinawa group: Okinawa Is. (after Nakane \& Kimoto, 1961).

Fukuoka: Mt. Atago, Mt. Tachibana in Fukuoka City; Tashiro, Kamihirokawamura in Yame-gun; Mt. Hiko; Mt. Wakasugi; Mt. Sefuri. Miyazaki: Miyazaki City. Kagoshima: Sata-misaki. Tokushima: Akuimachi in Tokushima City. Kochi : Jinzenj in Kochi City; Sukumo City. Tottori: Hoki-Daisen. Fukui : Takefu City. Nagano: Asama-Onsen.

Hosts: Acalypha australis; Fatuoa villosa (after Ohno, 1960).

\section{Altica oleracea (Linnaeus) (Fig. 7d)}

Chrysomela oleracea L., 1758, Syst. Nat., ed. 10, 372 (Europe).

Haltica oleracea: Motschulsky, 1886, Soc. Imp. Nat. Moscou, Bull. 39(1): 175 (Japan). Altica oleracea: Ohno, 1960, Toyo Univ., Bull. Dept. Lib. Arts 1:78, 84 (Hokkaido, Honshu, Kyushu; Amur, Turkestan, Persia, Asia Minor, Caucasia, Europe).Chûjô \& Kimoto, 1961, Pac. Ins. 3 (1): 171 (Europe, Caucasus, Asia Minor, Persia, Turkestan, Amur, Japan).

Distribution: Europe, Caucasus, Asia Minor, Iran, Turkestan, Amur, Japan (Hokkaido, Honshu, Kyushu).

Fukuoka: Komorino in Kurume City. Nagano: Karuizawa. Yamanashi: Amariyama; Shosenkyo; Kiyosato. Tochigi: Nikko. Hokkaido: Engaru in Abashiri.

Hosts: Epilobium angustifolium, E. pyrricholophium var. pyrricholophium; Oenothera Lamarckiana (after Ohno, 1960).

\section{Altica cirsicola Ohno (Fig. 8a)}

Altica cirsicola Ohno, 1960, Toyo Univ., Bull. Dept. Lib. Arts 1: 81, pl. 1, fig. VII, pl. 2, figs. 5, 6 (Mt. Jinmuji in Kanagawa Pref., and many other localities in Hokkaido, Honshu and Kyushu).-Chûjô \& Kimoto, 1961, Pac. Ins. 3 (1): 170 (Japan).-Gressitt \& Kimoto, 1963, Pac. Ins. Mon. 1B : 886, 888 (Japan, China).

As Ohno, 1960, stated, the specimens from N. Honshu and Hokkaido are rather large in size having slightly different male genitalia. It 
may be proved that this race represents an independent species. There are several specimens before me which were taken from Mt. Takao and Yunomata and belonging to the northern race. However, to solve the problem it is necessary to accumulate further material.

Distribution: China, Japan (Hokkaido, Honshu, Shikoku, Kyushu, Ryukyu Is. (Ishigaki).

Sakishima group: Ishigaki Is. (after Nakane \& Kimoto, 1961).

Fukuoka: Mt. Hiko; Mt. Wakasugi. Kagoshima: Sata-misaki. Kochi : Kajigamori in Nagaoka-gun. Tokyo: Mt. Takao. Aomori: Yunomata in Shimokita Pen.

Hosts: Circium spp. (after Ohno, 1960).

\section{Altica viridicyanea (Baly) (Fig. \&b)}

Graptodera viridicyanea Baly, 1874, Ent. Soc. Lond., Trans. 1874: 199 (Nagasaki; BM).

Haltica viridicyanea: Maulik, 1926, Fauna India, Chrysom. \& Halt., 422 (India, Japan). -Chen, 1934, Sinensia 5 (3-4): 392 (China, S. Korea, India, Japan).-Chûjô, 1936, Nat. Hist. Soc. Formosa, Trans. $26: 25,26$ (Honshu, Kyushu, Tsushima, Sakishima Group ; Formosa, China, India).

Altica viridicyanea: Ohno, 1960, Toyo Univ., Bull. Dept. Lib. Arts 1: 78, 86 (Honshu, Shikoku, Kyushu, Tsushima, Tanegashima; Loockoo ; Korea, Manchuria, China, India).-Chûjô \& Kimoto, 1961, Pac. Ins. 3 (1): 177 (Japan, Korea, China, Manchuria, India).-Gressitt \& Kimoto, 1963, Pac. Ins. Mon. 1B: 887, 892 (Japan, Ryukyu Is., Korea, China, India).

Distribution: India, China, Korea, Ryukyu Is. (Okinawa), Japan (Honshu, Shikoku, Kyushu, Tsushima, Tanegashima).

Fukuoka: Mt. Hiko, Ropponmatsu in Fukuoka City; Mt. Inunaki; Magaribuchi in Sawara-gun; Mt. Kora in Kurume City; Mt. Wakasugi. Oita: Mt. Sobo. Kochi : Jinzenji in Kochi City. Okayama: Kamo-cho in Tomata-gun. Osaka: Mt. Myoken.

Host: Geranium nepalense var. Thunbergii (after Ohno, 1960).

\section{Altica kurosawai Ohno (Fig. 8c)}

Altica kurosawai Ohno, 1960, Toyo Univ., Bull. Dept. Lib. Arts 1: 87, pl. 2, fig. 13 (Mt. Ohtakine in Fukushima Pref., Oyama in Fukushima Pref., Mt. Iide in Fukushima Pref., Shiga-kogen in Nagano Pref., Sanze-Yura in Yamagata Pref., Jimba in Akita Pref.; OнNo).—Chûjô \& Kimoto, 1961, Pac. Ins. 3 (1): 171 (Japan).

Distribution: Japan (Honshu).

One paratype is preserved in the collection of the Entomological Laboratory, Kyushu University.

Host: Geranium nepalense var. Thunbergii (after Ohno, 1960).

\section{Altica fragariae (Nakane) (Fig. 8d)}

Haltica fragariae Nakane, 1955, Saikyo Univ., Sci. Rep. 2 (1): A38, pl. 3, fig. 20 
(Japan: Zentsuji in Kagawa Pref., Tokushimashi in Tokushima Pref.; NaKane). Altica fragariae: Ohno, 1960, Toyo Univ., Bull. Dept. Lib. Arts. 1: 79, 88 (Shikoku, Kyushu).-Chûjô \& Kimoto, 1961, Pac. Ins. 3 (1): 170 (Japan).

Altica sanguisorbae Ohno, 1960, Toyo Univ., Bull. Dept. Lib. Arts 1: 83, pl. 1, fig. IV, pl. 2, fig. 12 (Kanayama-toge in Yamanashi Pref.; OHNo).-Chûjô \& Kimoto, 1961, Pac. Ins. 3 (1) : 172 (Japan). New Synonymy

Distribution: Japan (Honshu, Shikoku, Kyushu), China.

Fukuoka: Shikanoshima in Kasuya-gun; Mi. Hiko. Tottori: Iloki-Daisen. Yamanashi : Obinayama.

Hosts: Duchesnea indica, D. major; Fragaria chiloensis var. ananassa; Potentilla centrigrana; Sanguisorba officinalis (after Ohno, 1960). 